\title{
Repeated Mild Traumatic Brain Injury: Potential Mechanisms of Damage
}

Cell Transplantation

2017, Vol. 26(7) II3।-II55

(C) The Author(s) 2017

Reprints and permission:

sagepub.com/journalsPermissions.nav

DOI: $10.1177 / 0963689717714092$

journals.sagepub.com/home/cl

@SAGE

\author{
Brooke Fehily' and Melinda Fitzgerald ${ }^{1,2,3}$
}

\begin{abstract}
Mild traumatic brain injury (mTBI) represents a significant public healthcare concern, accounting for the majority of all head injuries. While symptoms are generally transient, some patients go on to experience long-term cognitive impairments and additional mild impacts can result in exacerbated and persisting negative outcomes. To date, studies using a range of experimental models have reported chronic behavioral deficits in the presence of axonal injury and inflammation following repeated $\mathrm{mTBl}$; assessments of oxidative stress and myelin pathology have thus far been limited. However, some models employed induced acute focal damage more suggestive of moderate-severe brain injury and are therefore not relevant to repeated $\mathrm{mTBI}$. Given that the nature of mechanical loading in TBI is implicated in downstream pathophysiological changes, the mechanisms of damage and chronic consequences of single and repeated closed-head mTBI remain to be fully elucidated. This review covers literature on potential mechanisms of damage following repeated $\mathrm{mTBI}$, integrating known mechanisms of pathology underlying moderate-severe TBls, with recent studies on adult rodent models relevant to direct impact injuries rather than blast-induced damage. Pathology associated with excitotoxicity and cerebral blood flow-metabolism uncoupling, oxidative stress, cell death, blood-brain barrier dysfunction, astrocyte reactivity, microglial activation, diffuse axonal injury, and dysmyelination is discussed, followed by a summary of functional deficits and preclinical assessments of therapeutic strategies. Comprehensive characterization of the pathology underlying delayed and persisting deficits following repeated mTBI is likely to facilitate further development of therapeutic strategies to limit long-term sequelae.
\end{abstract}

\section{Keywords}

repeated mild traumatic brain injury, pathology, functional deficits, reactive gliosis, oxidative stress, myelin abnormalities

\section{Introduction}

Traumatic brain injury (TBI) encompasses structural brain damage or physiological alteration in brain function resulting from an external force. ${ }^{1}$ Worldwide, the leading causes of TBI are falls and motor vehicle accidents, resulting in an estimated 10 million deaths and/or hospitalizations annually ${ }^{2}$; TBI is the leading cause of mortality and morbidity for persons under $45 \mathrm{y}$ of age. ${ }^{3}$ TBI is a robust environmental risk factor for neurodegenerative disorders, ${ }^{4}$ and chronic sequelae may lead to permanent disability and ongoing care and cost. ${ }^{5}$ Currently, therapeutic interventions for TBI are lacking.

TBI can be mechanically induced by blunt or penetrating impacts, non-impact blast waves, or inertial loading. While penetrating injuries are typically synonymous with severe TBI, other causes of injury do not necessarily lead to specific injury severity or prognosis. As such, classification systems are employed to delineate TBI severity, based on clinical presentation and structural findings. ${ }^{6}$ Clinical severity is determined using the universally accepted Glasgow Coma Scale, ${ }^{7}$ which scores ocular, motor, and verbal responses on a scale of 3-15.
Mild TBI (mTBI) patients score 13-15, moderate TBI patients score 9-12, while severe injuries score $<9$. Additionally, traditional neuroimaging techniques such as magnetic resonance imaging and computed tomography are employed to detect the presence of gross lesions, allowing a broad differentiation between focal and diffuse damage. ${ }^{8}$ Patients diagnosed with

' Experimental and Regenerative Neurosciences, School of Biological sciences, The University of Western Australia, Perth, Western Australia, Australia

${ }^{2}$ Curtin Health Innovation Research Institute, Curtin University, Perth, Western Australia, Australia

${ }^{3}$ Perron Institute for Neurological and Translational Science, Sarich Neuroscience Research Institute, Nedlands, Western Australia, Australia

Submitted: July 04, 2016. Accepted: August 0I, 2016.

\section{Corresponding Author:}

Melinda Fitzgerald, School of Biological Sciences, The University of Western Australia (M317), 35 Stirling Highway, Perth, Western Australia 6009, Australia.

Emails: lindy.fitzgerald@uwa.edu.au; lindy.fitzgerald@curtin.edu.au 
moderate or severe TBIs are often grouped together, as they exhibit gross structural damage on neuroimages. Overt abnormalities are typically focal in nature and can include cerebral contusions, extra or subdural hematomas, subarachnoid hemorrhage, intracranial or intraventricular bleeding, or skull fractures. ${ }^{9}$ On the other hand, patients diagnosed with a mTBI exhibit normal neuroimaging ${ }^{10}$; however, it is important to note that microscopic damage such as diffuse axonal injury (DAI) is undetectable using traditional neuroimaging techniques. ${ }^{6}$ As such, a diagnosis of $\mathrm{mTBI}$ is determined on clinical observation or self-reported symptoms; the term concussion is generally used interchangeably to define the clinical syndrome. ${ }^{11}$ Hereafter, mTBI will be used to describe these injuries.

\section{Mild and Repeated $\mathbf{m T B I}$}

Epidemiological research indicates that $70-90 \%$ of all TBIs are mild, with incidence likely to be substantially underestimated. ${ }^{12}$ Mild head trauma is common among professional athletes engaged in contact and collision sports ${ }^{2}$ and military personnel $1^{13}$; this review will focus on models of mTBI more relevant to sports-related injury. The primary cause of mTBI in sports is the application of both linear and rotational acceleration and impact deceleration forces to the brain, inducing nonpenetrating diffuse rather than focal damage. ${ }^{14-16}$ Typically, mTBI is characterized by a transient disturbance in brain function, with short-lived neurological symptoms including headache, dizziness, and confusion. ${ }^{17}$ Symptoms for most patients generally subside within $10 \mathrm{~d}$ of injury ${ }^{18}$; however, they can persist with 10-40\% developing postconcussion syndrome, ${ }^{19-21}$ associated with long-term cognitive deficits and white matter changes. ${ }^{22}$ While a single mTBI may not always result in behavioral impairments, clinical research suggests that further injuries induce cumulative effects, by both increasing the susceptibility for further mTBI and progressing to longterm functional deficits ${ }^{23,24}$ and underscoring the importance of "return to play" guidelines in sports. In particular, retired American football athletes with a history of repeated mTBI show elevated rates of cognitive impairment, ${ }^{25}$ long-term psychiatric illness, and an increased incidence of chronic traumatic encephalopathy (CTE), a progressive tauopathy. ${ }^{26-28}$ This review focuses on potential mechanisms of damage underlying the cumulative and chronic effects of repeated "closed-head" mTBI, referring to single mTBI in the context of studies exploring subsequent injuries. For more detailed discussion of single mTBI, the reader is referred to Dewitt et al. ${ }^{29}$ for review. The importance of using clinically relevant experimental models of mTBI is receiving increasing attention and will be touched upon here (see Xiong et al., ${ }^{30}$ Angoa-Pérez et al., ${ }^{31}$ Laplaca et al., ${ }^{32}$ Namjoshi et al., ${ }^{33}$ and Zhang et al. ${ }^{34}$ for further insights).

\section{Experimental Models of TBI: Toward Clinical Relevance}

In order to develop therapeutic strategies to prevent or ameliorate long-term damage and deficits following repeated
mTBI, an understanding of the pathophysiological cascade of events and the mechanistic link between acute and chronic mTBI pathology needs to be elucidated. This can only be achieved using experimental models that suitably approximate the forces behind the primary injury, producing structural and functional deficits akin to human mTBI. Further, there is a threshold for the generation of injury and its potential exacerbation by repeated traumatic insults, with implications for long-term outcome measures. As such, additional considerations in experimental design include severity and number of impacts as well as inter-injury interval. As the majority of studies exploring repeated mTBI have used young adult rats of 2-3 mo of age, this review will focus on studies using adult rodents.

The majority of mechanistic TBI studies have used models incorporating stereotaxic head restraint, anesthesia, a craniotomy, and direct impact onto the brain to induce focal injuries and marked acute behavioral deficits. However, human mTBI features head movement in the absence of dural penetration and structural and functional deficits are subtle. Craniotomies ${ }^{35}$ and anesthesia ${ }^{36}$ in rodent models of mTBI likely confound damage, particularly if repeated, and do not reflect the human injury. While there are no universally accepted criteria for validity in mTBI models, nonpenetrating mechanical input, without acute focal damage and incorporating linear and rotational forces, is intuitively desirable. Indeed, confirming the absence of skull fracture, hemorrhage and acute cell death, and/or neuronal degeneration following mTBI is becoming commonplace. ${ }^{29}$ An absent or mild acute behavioral phenotype and the capacity for repeated injury are further useful attributes of a suitable model of repeated $\mathrm{mTBI}$.

However, given the heterogeneity of TBIs in humans, and inherent lack of face validity of animal models, no single experimental model can mimic the entire complexity of TBIinduced pathology. While closed-head models incorporating both linear and rotational forces are more appropriate to model single and repeated mTBI, it is nevertheless important to consider "open-head" models causing moderate and severe injuries for what they can tell us about mechanisms of pathology.

\section{Open-head Models of TBI}

Open-head experimental models, namely, lateral fluid percussion (LFP) $)^{37}$ and controlled cortical impact (CCI), ${ }^{38}$ have been extensively utilized to explore moderate-severe TBI. Within experiments, direct force onto the brain imparts highly reproducible focal damage, though changes in craniotomy position translate to variable outcomes between laboratories. ${ }^{39}$ In the LFP model, a pendulum strikes a fluid-filled reservoir, and pressure from a fluid-filled bolus is forced into the epidural space, ${ }^{37,40}$ The LFP model typically induces focal damage such as hemorrhage and edema at the site of impact, with progressive subcortical cell death, ${ }^{41-43}$ thereby replicating many structural, 
pathological, and neurobehavioral features of moderatesevere human TBIs. LFP has been used to model single ${ }^{44}$ and repeated mTBI, ${ }^{45-47}$ by lowering the pendulum height to reduce the pressure pulse and therefore injury severity. However, focal cell loss in control animals receiving a single "mild" TBI may still remain.

In the CCI model, an electromagnetic or pneumatically driven piston directly penetrates the underlying cortex from a known distance and velocity. ${ }^{38}$ Deformation of the underlying cortex induces cortical cell loss and subdural hematoma ${ }^{37}$ and leads to more diffuse axonal injuries than the LFP model ${ }^{48,49} \mathrm{CCI}$ simulates many pathological and behavioral outcomes characteristic of moderate-severe TBI in humans, and injury severity can be graded by adjusting impact depth and velocity. ${ }^{30}$ Indeed, CCI is extensively employed to model repeated mTBI, ${ }^{50-52}$ including closedhead variations without focal damage ${ }^{53-57}$ and incorporating acceleration-deceleration forces. ${ }^{58,59}$ However, care must be taken when interpreting findings referred to in publications as mild or repeated mild CCI, as head movement upon impact is still predominantly restricted.

\section{Closed-Head Models of TBI}

In addition to closed-head mild CCIs, weight-drop (WD) models are capable of delivering a diffuse injury through the intact skull. While the first WD models mainly induced focal damage, with ${ }^{60}$ or without a craniotomy, ${ }^{61,62}$ subsequent closed-head models were developed to produce more diffuse damage. ${ }^{63,64}$ In Marmarou's WD impactacceleration model, a free-falling weight is guided down a tube, striking a steel disk placed on the rodent's exposed skull, preventing skull fracture. ${ }^{63}$ As the rat rests on a piece of foam, slight movement of the head is allowed, thereby transmitting some acceleration forces. The result is widespread damage of neurons and axons alongside severe compression of the cranial vault, suitably modeling nonpenetrating moderate-severe TBI.

In recent years, the heaviness of the weight and the drop height have been modified and titrated to eliminate focal cortical injury as an acute feature. ${ }^{65-69}$ Increasing amounts of head movement have also been incorporated, ${ }^{70-72}$ to more closely approximate human head kinematics following mTBI. ${ }^{73}$ As such, WD models are increasingly utilized to model repeated mTBI. To incorporate rapid translational and angular acceleration forces, the animal is rested on a Kimwipe, ${ }^{72}$ aluminum foil ${ }^{70,71}$ or traversable "trap door" ${ }^{, 74}$ suspended on a hole in the center of the apparatus stage. The impact results in unrestricted movement of the head and body as the animal readily penetrates the material upon impact and free falls onto a padded cushion below.

Various other models have been developed to increase rotational acceleration ${ }^{75}$ and employ momentum-exchange principles in a frontal impact model ${ }^{76,77}$ through the use of a pendulum striker ${ }^{78,79}$ as well as projectiles. ${ }^{80,81}$ Mechanical input parameters and subsequent outcomes can be more variable in closed-head models incorporating rotational head movement. ${ }^{33}$ However, resulting tissue strains are greater than those produced by the pure translational forces that define open-head models ${ }^{16,82}$ and are more reflective of human head movement following impact-related mTBI.

\section{Mechanisms of Pathology Following TBI}

TBI is traditionally characterized by primary and secondary injury phases, both contributing to the extent of damage. ${ }^{83}$ The primary injury represents acute disturbances and/or damage induced at the moment of impact, while secondary injury mechanisms, collectively known as secondary degeneration, involve a cascade of downstream interacting pathophysiological mechanisms. ${ }^{15}$ In mild and repeated mTBI, however, there is no clear spatial separation between primary and secondary injury, and mechanisms of pathology remain insufficiently characterized. In a single mTBI, a dynamic restorative process likely underpins the transient alteration in brain function. ${ }^{84}$ In contrast, the long-term sequelae of repeated mTBI are more reminiscent of moderate-severe injuries, suggesting that similar underlying cellular and metabolic events are occurring in repeated mTBI, albeit to a reduced degree and in a starkly different temporal progression. ${ }^{85,86}$ It remains to be elucidated whether this worsening of long-term outcome is due to a cumulative effect of subsequent mTBIs or the independent or synergistic action of secondary processes exacerbating outcome. Herein, mechanisms of damage known to occur in moderate-severe TBI are described, with specific reference to evidence from repeated mTBI literature where available. Table 1 provides further study-specific information of known pathology in the various repeated mTBI models.

\section{Excitotoxicity and Cerebral Blood Flow-Metabolism Uncoupling}

In moderate-severe TBI, the initial impact mechanically disrupts axolemma and neuronal plasmalemma protein channels, causing immediate depolarization and dysregulated ionic homeostasis. ${ }^{87}$ Indiscriminate release of excitatory amino acids, particularly glutamate, exacerbates potassium $\left(\mathrm{K}^{+}\right)$efflux in a severity-dependent fashion. ${ }^{88}$ Overactivation of glutamate receptors and voltage-gated calcium $\left(\mathrm{Ca}^{2+}\right)$ channels facilitates $\mathrm{Ca}^{2+}$ influx, triggering mitochondrial $\mathrm{Ca}^{2+}$ sequestration, $\mathrm{Ca}^{2+}$-dependent $\mathrm{Ca}^{2+}$ release from intracellular stores, and dramatically elevated cytosolic $\mathrm{Ca}^{2+} \cdot{ }^{89}$ Further, excessive $\mathrm{Ca}^{2+}$ influx can initiate cell death pathways ${ }^{90}$ and lead to compaction of neurofilaments, microtubule disassembly, and impaired axonal transport, coupled with eventual swelling and axotomy. ${ }^{91}$ In moderate-severe TBI, $\mathrm{Ca}^{2+}$ accumulation as measured by isotopelabeled $\mathrm{Ca}^{2+}$ can persist for up to $1 \mathrm{wk}$, concomitant with memory deficits in the Morris water maze (MWM).$^{92}$ Additionally, $\mathrm{Ca}^{2+}$-induced depolarization of the mitochondrial membrane allows electron leakage to oxygen in the electron 


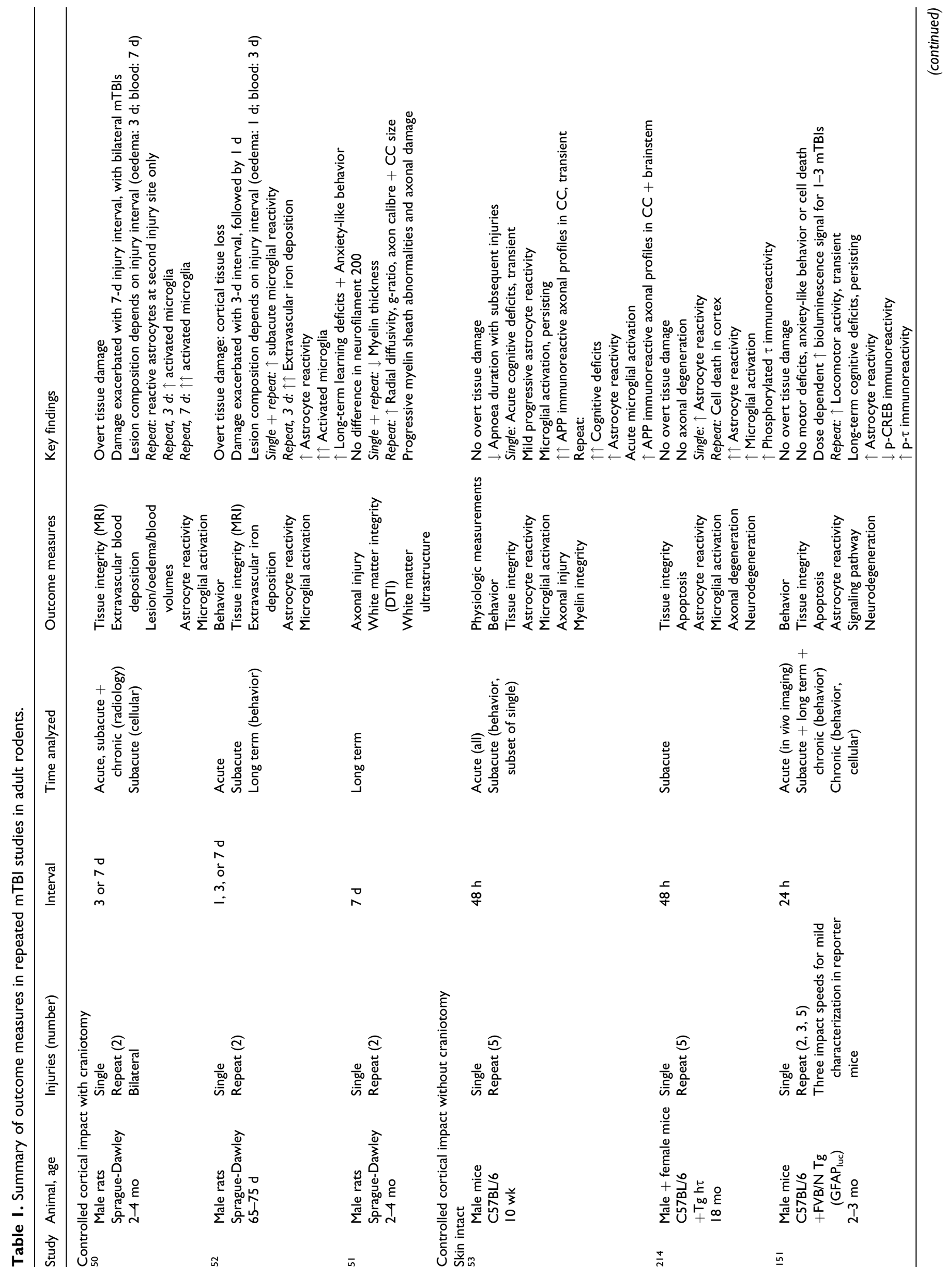




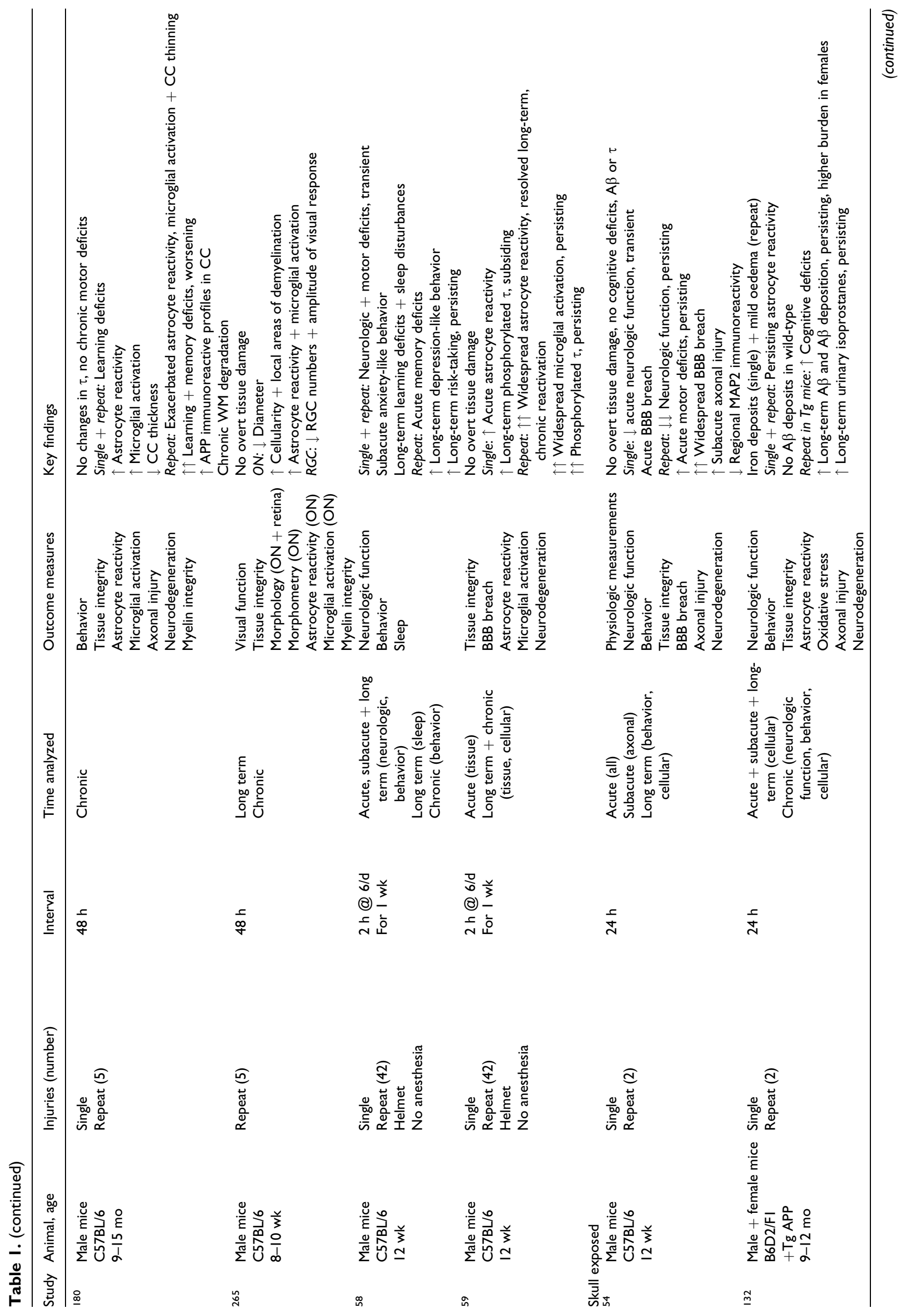




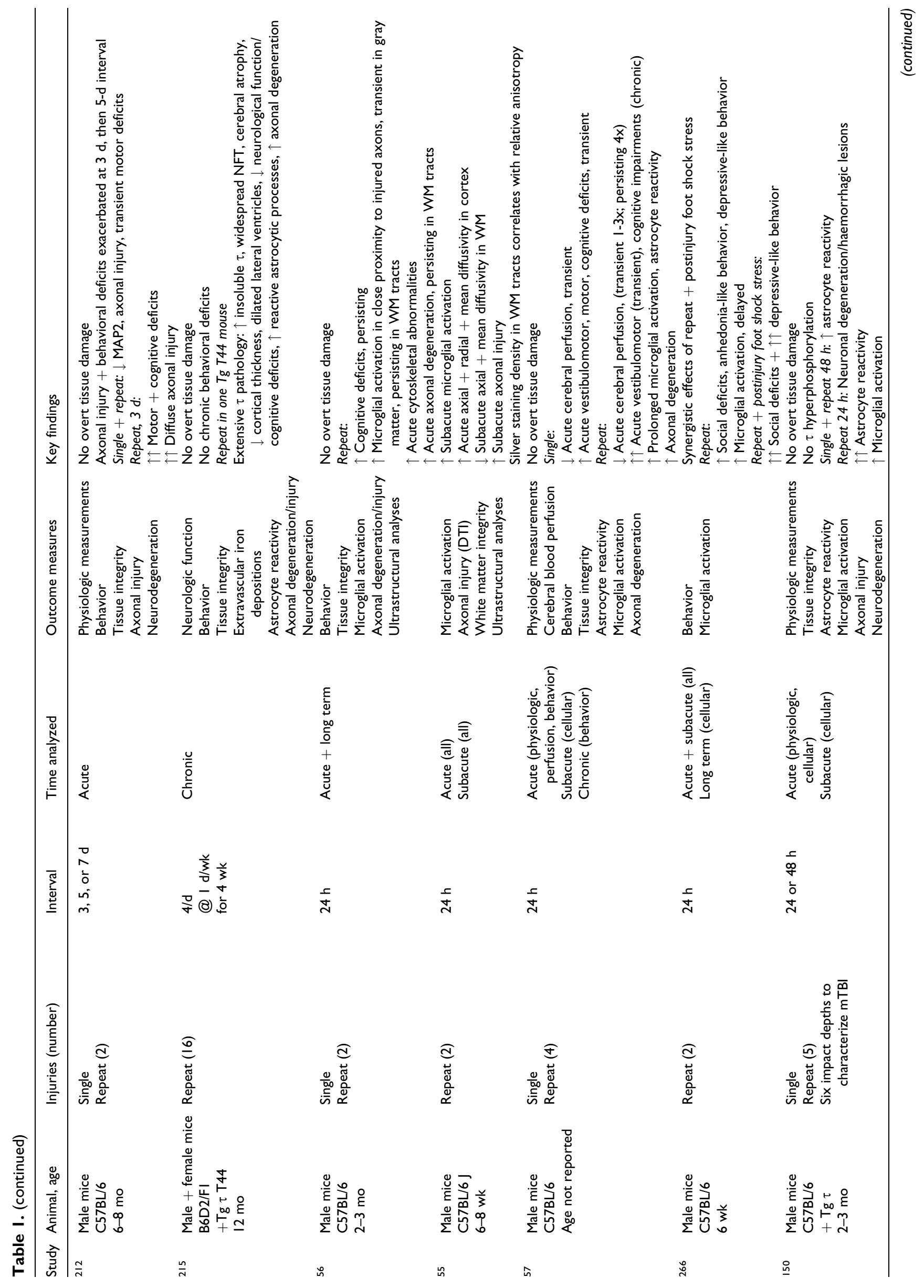




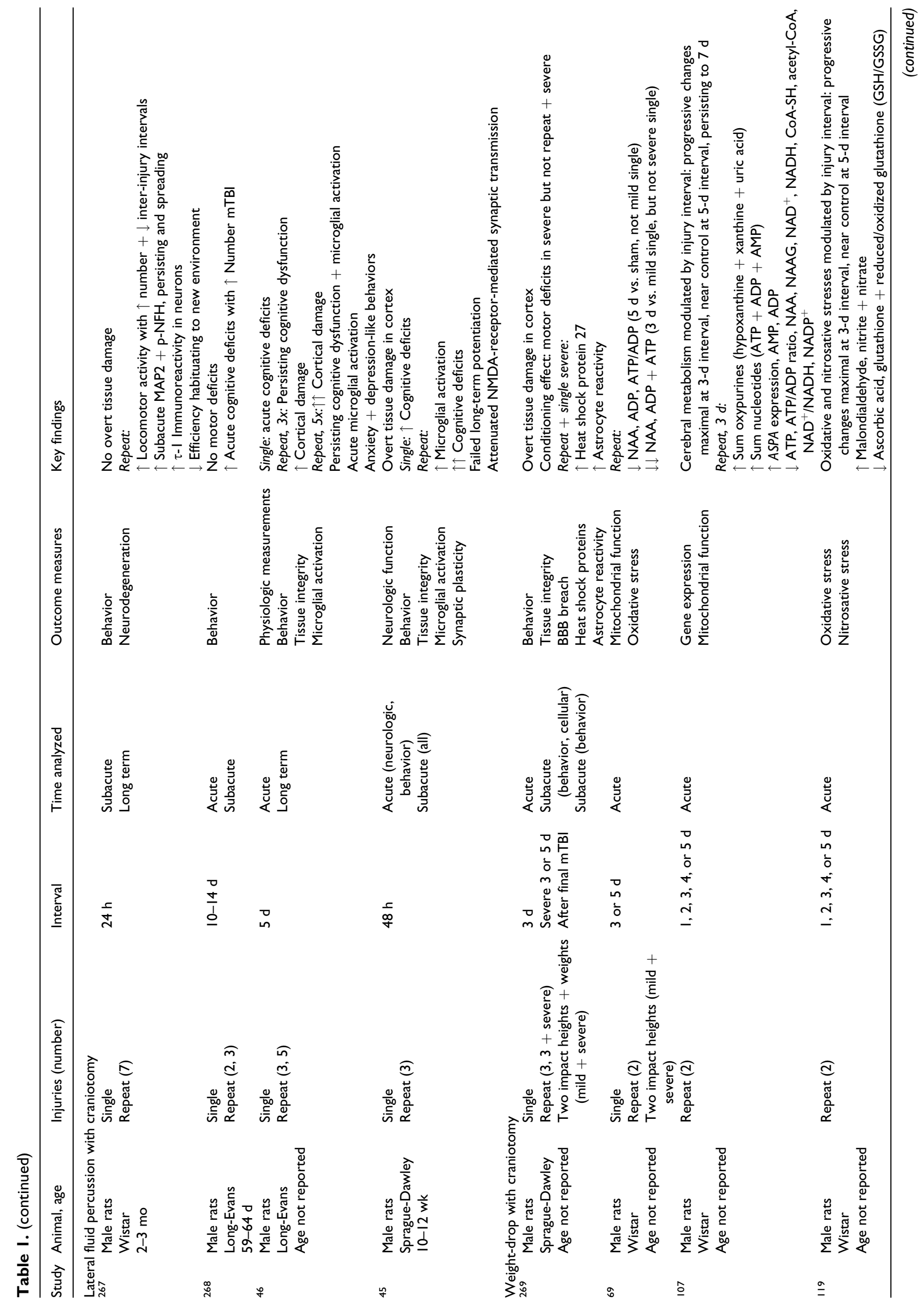




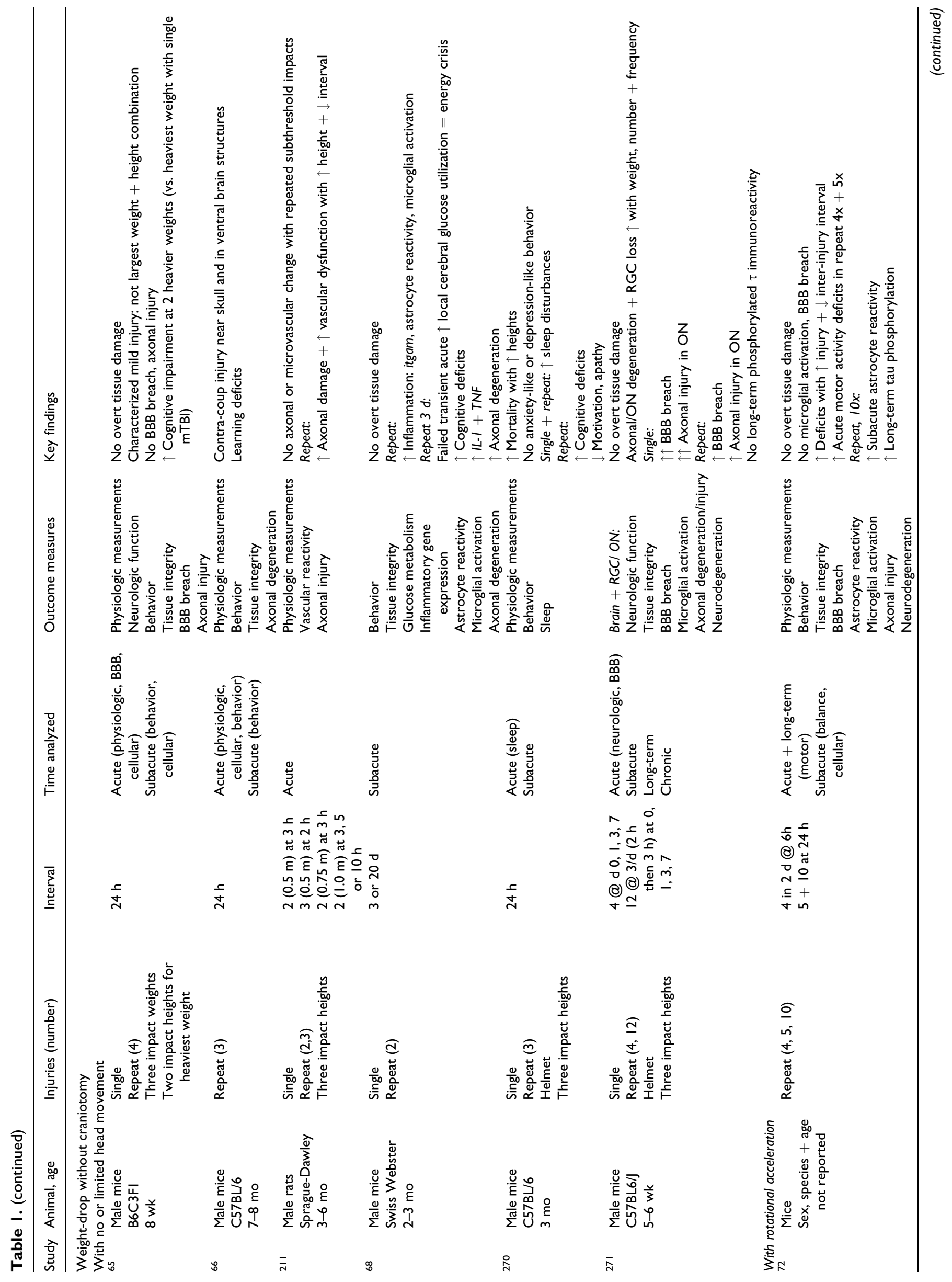




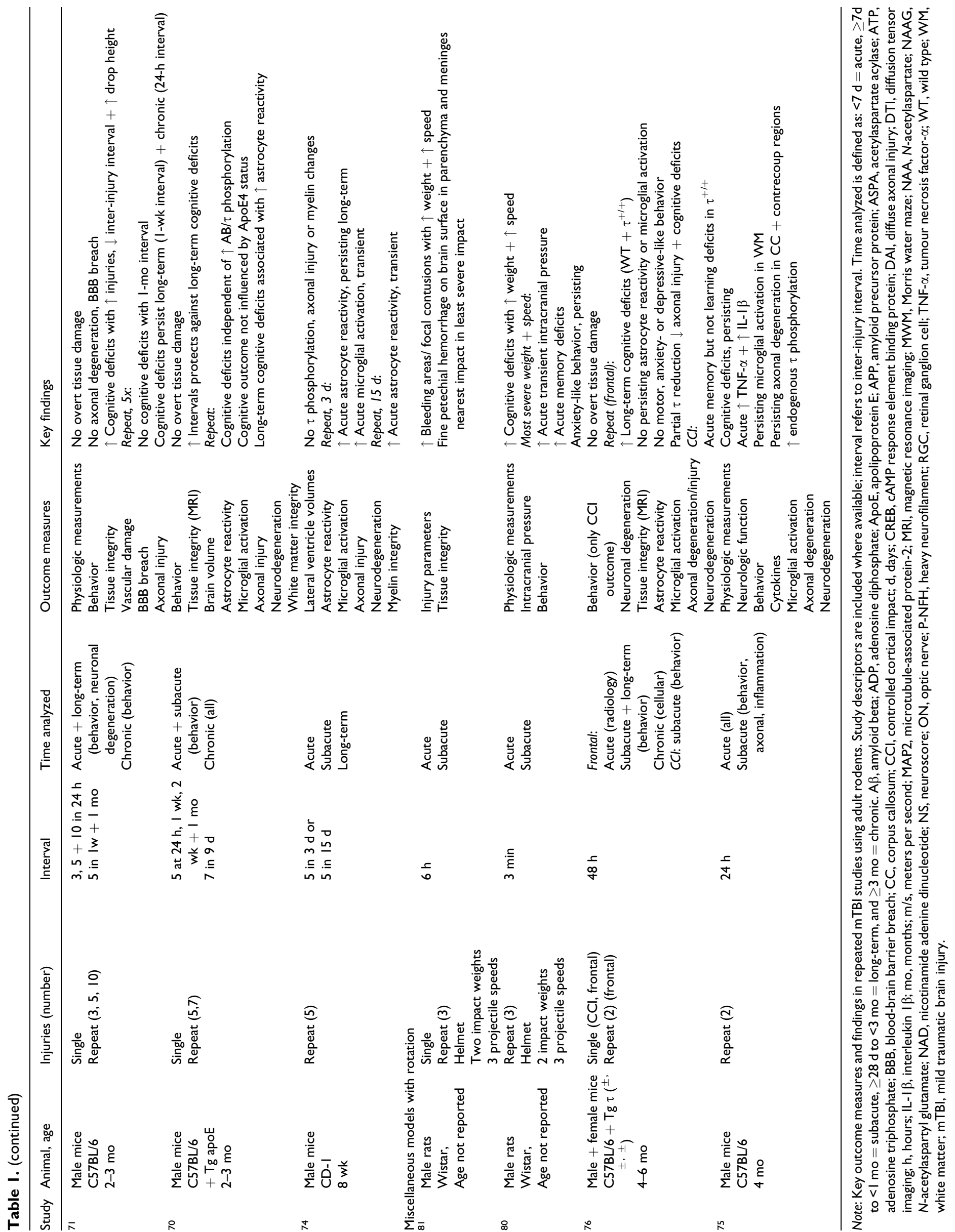


transport chain, uncoupling oxidative phosphorylation, and suppressing adenosine triphosphate (ATP) synthesis in a CCI model. ${ }^{93}$ ATP-dependent pumps are engaged to restore TBI-induced ionic imbalances, resulting in a transient increase in cerebral glucose uptake. ${ }^{94}$ In a closed-head model of diffuse TBI, mitochondrial dysfunction, as measured by ATP and $n$-acetyl aspartate reductions, positively correlates with injury severity. ${ }^{95,96}$ Concomitant with hyperglycolysis, acute decreases in cerebral blood flow (CBF) have been well-documented in experimental models, ${ }^{97,98}$ and this failure to meet increased energy demands induces a severity-dependent metabolic crisis. ${ }^{99}$ A subsequent period of hypoglycolosis can ensue. ${ }^{90,97,100}$ While complete recovery typically occurs within $10 \mathrm{~d},{ }^{101}$ the precise longevity correlates with severity, ${ }^{102}$ behavioral deficits, ${ }^{103}$ and progressive white matter damage above a certain threshold. ${ }^{90}$ Interestingly, effects of applying a secondary insult such as ischemia or bilateral carotid occlusion following $\mathrm{CCI}^{99,104,105}$ and $\mathrm{WD}^{106}$ suggest that the critical temporal CBF-metabolic uncoupling period reflects a window of vulnerability of increased susceptibility. In a repeated moderate TBI WD study, an inter-injury interval of 1-3 d induces maximal damage in a range of metabolic outcome measures. ${ }^{107}$ The state of metabolic depression reflects an altered cerebral state that is associated with functional deficits and has been proposed to reflect a "window of vulnerability" or vulnerable cerebral state. ${ }^{107}$

\section{CBF-Metabolism Uncoupling Following Repeated mTBI}

Aligning with the acute temporal profile of ionic fluxes and metabolic events characterizing moderate TBIs, ${ }^{91}$ it has been suggested that acute ionic imbalances and energy dysregulation following a single mTBI also represent a temporal window of vulnerability that is associated with acute behavioral deficits ${ }^{107,108}$ and increased susceptibility to damage with further insults. ${ }^{54,69,71}$ Indeed, while acute cerebral hypometabolism, mitochondrial dysregulation, and cognitive deficits resolve within $1 \mathrm{wk}$ following a single WD mTBI, a second injury delivered after a 3 but not $20 \mathrm{~d}$ interval, resulted in exacerbated metabolic dysregulation concomitant with cumulative cognitive deficits. ${ }^{68}$ While the implications of these findings on long-term outcome remain unexplored, it is possible that these earlier chemical vulnerabilities may be the impetus for longer-lasting metabolic cascades.

\section{Oxidative Stress}

There is a highly interactive relationship between glutamate excitotoxicity, intracellular $\mathrm{Ca}^{2+}$ accumulation, metabolic depression, and reactive oxygen species (ROS) production, ${ }^{109-111}$ and the latter is thought to mediate neurotrauma-induced secondary degeneration. ${ }^{112} \mathrm{TBI}$ is characterized by increases in both ROS and reactive nitrogen species production as a consequence of excessive ${ }^{113}$ intracellular $\mathrm{Ca}^{2+}$ as well as decreases in enzymatic or nonenzymatic antioxidants such as manganese superoxide dismutase glutathione peroxidase, ascorbic acid, and glutathione. ${ }^{114-116}$ When excess ROS and reactive nitrogen species overcome endogenous antioxidant capacities, the state of metabolism is referred to as oxidative stress. ${ }^{17}$ Subsequent oxidation of lipids, proteins, and DNA to toxic metabolites causes cellular dysfunction ${ }^{118}$; ROS-mediated tissue damage has been positively correlated with TBI severity. ${ }^{119,120}$

Oxidative stress after TBI predominantly manifests as lipid peroxidation, likely attributable to the brain's high polyunsaturated fatty acid (PUFA) content. ${ }^{121}$ In a rat focal contusion model, a progressive increase in lipid hydroperoxides is observed following an immediate post-traumatic burst in hydroxyl radical formation. ${ }^{122}$ ROS-mediated lipid peroxidation, measured by 4-hydroxynonenal ${ }^{123}$ and malondialdehyde concentrations, ${ }^{124}$ respectively, is similarly increased following moderate CCI and WD TBI. Additionally, lipid peroxidation has been associated with blood-brain barrier (BBB) damage following CCI TBI. ${ }^{122}$ Acute increases in protein nitration ${ }^{125}$ and DNA damage ${ }^{123}$ can also occur following TBI, while excessive ROS may also trigger caspase-dependent ${ }^{126}$ and -independent cell death pathways. ${ }^{127}$

In a repeated moderate WD study, increases in reduced glutathione/oxidized glutathione, and nitrate and nitrite stressors, together with decreases in the antioxidant ascorbic acid were observed $48 \mathrm{~h}$ after final injury, when 2 moderate TBIs were given $1-3$, but not $5 \mathrm{~d}$ apart. ${ }^{119}$ While studies are limited, these findings provide further support for an acute temporal period of compromised cellular defenses in the brain, with modulation of oxidative and nitrosative stressors by injury interval and a cumulative effect of increased ROS production following repeated moderate TBI implicating oxidative stress in the proposed window of vulnerability. Beyond this, oxidative stress following moderate-severe TBI feeds back to and propagates $\mathrm{Ca}^{2+}$-induced glutamate excitotoxicity and mitochondrial dysfunction. Further, long-term oxidative stress plays a pivotal role in neurodegeneration ${ }^{128,129}$ and potentially in the pathogenesis of neurodegenerative diseases. ${ }^{130,131}$

\section{Oxidative Stress Following Repeated mTBI}

Given the progressive nature of pathology and long-term negative outcomes following repeated mTBI, oxidative stress is implicated as a driver of damage. However, studies exploring oxidative stress in the context of repeated mTBI are scarce. A transgenic mouse model of Alzheimer's disease-like amyloidosis has been used to explore the relationship between repeated mTBI and neurodegenerative disease. ${ }^{132,133}$ A transient increase in isoprostanes, a product of free radical peroxidation of PUFAs, is reported following a single mild CCI, and a subsequent injury given after $24 \mathrm{~h}$ results in exacerbated lipid peroxidation that persists to 4 mo. Increased isoprostanes is associated with greater cognitive impairment and accelerated brain amyloid beta $(A \beta)$ 
protein accumulation and deposition ${ }^{132}$; similar findings have been reported elsewhere. ${ }^{133}$

\section{Cell Death}

Injury-induced neuronal and glial cell death likely occurs along a continuum of necrotic (passive) and/or apoptotic (programmed) mechanisms, ${ }^{134,135}$ resulting in removal of injured and dysfunctional cells, but also progressive neuronal degeneration and exacerbated functional deficits. ${ }^{136,137}$ Necrotic cell death occurs under conditions of excitotoxicity and metabolic failure particularly prevalent at the site of impact immediately following focal TBI, while surviving cells spatially separated from the primary necrotic injury can undergo delayed and programmed cell death. ${ }^{3}$ Caspase- 3 triggers cell death in $\mathrm{CCI}^{138}$ and $\mathrm{LFP}^{139}$ TBI models, while in a moderate-severe rat CCI study, protein unfolding following endoplasmic reticulum stress activates capase- $12^{140}$ and elevated capsase- 12 messenger RNA in a severitydependent manner. ${ }^{141}$ In a severe CCI model, conditions of impaired mitochondrial respiration and oxidative/nitrosative stress are associated with apoptosis-inducing factor mediating cell death via poly(adenosine diphosphate ribose) polymerase-1-induced apoptosis, $6 \mathrm{~h}$ post-injury in the hippocampus. ${ }^{142}$ The maintenance of intact mitochondrial membrane potential is a critical factor in determining propensity toward apoptotic instead of necrotic mechanisms. ${ }^{14,144}$ It follows that the type, extent, and temporospatial distribution of cell death is closely related to injury type and severity. ${ }^{145}$ Further, significant reductions in mature oligodendrocytes in white matter tracts are observed acutely, ${ }^{44}$ subacutely, ${ }^{146,147}$ and persisting to $1 \mathrm{mo}^{148,149}$ following moderate LFP and CCI TBI. Concomitant temporal and spatial association with increased caspase-3 expression ${ }^{146,148}$ indicates oligodendrocyte vulnerability to TBI-induced apoptosis in subcortical white matter that may underlie dysmyelination and contribute to secondary axonal injury.

\section{Cell Death Following Repeated mTBI}

Histological stains such as cresyl violet, hematoxylin and eosin, and fluorojade are used to assess cell death as an acute outcome following mTBI, with cell death is typically absent following single mTBI. ${ }^{54,56,65,70}$ One repeated mTBI study reported significant acute neuronal death in the entorhinal cortex and around hemorrhagic lesions, following 5 CCI mTBI given at $24 \mathrm{~h}$ intervals. ${ }^{150}$ Findings were deemed an outcome of both injury number and inter-injury interval, as a 48 -h interval prevented neurodegeneration ${ }^{150}$; however, a study using similar injury parameters and experimental design did not report neurodegenerative changes. ${ }^{151}$ While a threshold for injury severity exists, the typical absence of overt neuronal cell death at both acute and chronic time points suggests that neuronal dysfunction and diffuse axonal injury are greater contributors to the progressive nature and chronic sequelae of mTBI and repeated mTBI than death of neurons; little is known regarding the death of glial cells following repeated mTBI.

\section{Blood-Brain Barrier (BBB) Dysfunction}

The BBB is a highly dynamic system comprising a network of non-fenestrated endothelial cells connected by tight junctions surrounded by astrocytic end feet and pericytes that physically separate the intra- and extravascular central nervous system (CNS) content. ${ }^{152}$ In response to perturbations in the neurochemical microenvironment, BBB tight junctions, transporters, and enzymes are regulated to protect the brain from noxious circulating stimuli while ensuring nutrient supply. ${ }^{153,154}$ Following focal moderate-severe TBI, the BBB is breached, resulting in immediate infiltration of peripherally circulating leukocytes into the brain parenchyma. Together with the initiation of transcriptional changes in the neurovascular network, infiltrating cells aggravate the resident neuroinflammatory response, ${ }^{155,156}$ culminating in neuronal dysfunction and neurodegeneration and a feed forward loop of further neuroinflammation. ${ }^{157}$ Excessive excitatory amino acids, ROS, nitric oxide (NO) production, ${ }^{158}$ and upregulated proinflammatory cytokines ${ }^{159}$ contribute to and exacerbate BBB dysfunction and subsequent developing pathology. ${ }^{160,161}$

Primary mechanical injury may also damage endothelial cells, leading to capillary albumin extravasation and an increase in small vessel permeability. ${ }^{157,162}$ Temporal progression varies between animal models; BBB permeability increases immediately at the site of LFP injury with a hasty resolve, ${ }^{163}$ while an acute biphasic response is observed in a CCI model. ${ }^{164}$ Further, increased cerebral vascular permeability is reported 4-6 h following focal closed-head WD injury, with concomitant widespread protein leakage $e^{61,165}$ persisting for up for $4{ }^{166}$ and $7 \mathrm{~d}^{61}$ Such an extended opening of the BBB can exacerbate posttraumatic invasion of leukocytes ${ }^{167}$ and neutrophils. ${ }^{159}$ Detachment of vascular pericytes and migration into the parenchyma also occurs within $24 \mathrm{~h}$ following a moderate WD injury. ${ }^{168}$ While there are a multitude of factors contributing to the probability, severity, and longevity of negative long-term TBI-induced sequelae, ${ }^{169}$ there is increasing evidence of chronic inflammatory states in animal models of diffuse TBI, characterized by less pronounced leukocyte recruitment, ${ }^{3}$ and persisting microgliosis in white matter tracts, ${ }^{170,171}$ implicating dysfunction of the BBB in continuing pathology.

\section{BBB Dysfunction Following Repeated $m T B I$}

There are few reports of BBB dysfunction following repeated impact-related mTBI. Assessment of BBB integrity via permeability to immunohistochemically detected intracerebral mouse immunoglobulin $\mathrm{G}(\mathrm{IgG})$ and has indicated limited BBB breach. Specifically, following a single mild CCI, a small focal BBB breach was observed up to $48 \mathrm{~h}$ after 
injury, while a second injury given $24 \mathrm{~h}$ later resulted in increased cortical and white matter IgG immunoreactivity, with associated intraparenchymal serum extravasation that spread to white matter tracts. ${ }^{54}$ Although not measuring BBB disruption directly, 5 mild CCI TBIs delivered at either 24- or 48-h intervals revealed major histocompatibility complex class II-associated antigen-labeled macrophages in hemorrhagic lesions. ${ }^{150}$ Other repeated mTBI studies revealed no BBB compromise in $\mathrm{CCI},{ }^{59} \mathrm{WD},{ }^{65}$ or Kimwipe/aluminum foil models, ${ }^{71,72}$ although all analyses were conducted at acute time points.

\section{Astrocyte Reactivity}

Astrocytes are critical early responders to TBI-induced extracellular changes, becoming reactive in a process known as astrogliosis and exerting complex heterogeneous responses including altered gene expression, hypertrophy, and proliferation. ${ }^{172}$ Astrocytes regulate the inflammatory response and can subdue the spread of damage. Through membrane protein channels and engagement of ATPdependent pumps, astrocytes recycle excitatory amino acids to reduce glutamate excitotoxicity and restore $\mathrm{K}^{+}, \mathrm{Ca}^{2+}$, and $\mathrm{Na}^{+}$ionic homeostasis. ${ }^{173}$ Buffering excess extracellular $\mathrm{K}^{+}$, glutamate and ATP levels allow for provision of substrates for ATP synthesis and/or neuronal consumption to counter ROS-induced mitochondrial dysfunction and scavenge free radicals. ${ }^{174}$ However, astrocytes can also release free radicals and proinflammatory cytokines and exacerbate ATPinduced ATP release, triggering microglial activation and propagation of $\mathrm{Ca}^{2+}$ waves via the astrocytic syncytium. ${ }^{175,176}$ These dual neuroprotective and neurotoxic responses have been observed following LFP and CCI TBI and the balance between responses depends on the nature and severity of the injury. ${ }^{177-179}$ However, how astrocytes interact with surrounding cells to influence the progression of response to repeated mTBI is yet to be fully elucidated.

\section{Astrocyte Reactivity Following Repeated mTBI}

While astrocyte responses typically increase with mTBI severity, number, and decreased inter-injury interval, ${ }^{150,151}$ there is variability in reported time courses of response. A single mTBI can lead to a rapidly resolving ${ }^{151}$ or mildly progressive $^{53,150}$ astrogliosis in a closed-head CCI model. When 4 mTBIs at 24-h intervals are delivered in both WD rotational and CCI models, the astrocytic response is exacerbated at $1,{ }^{53,150} 7,{ }^{72}$ and $14 \mathrm{~d},{ }^{57}$ persisting to $6 \mathrm{mo}$, with concomitant cognitive deficits. ${ }^{70}$ Increasing the inter-injury interval to $1 \mathrm{wk}$ results in no observable response, ${ }^{70}$ indicating that longer inter-injury intervals may be protective. Intermediate inter-injury intervals of $48 \mathrm{~h}$ yield variable outcomes. ${ }^{150,180}$ Intriguingly, however, there is relative consistency in the progressive spread of the astroglial response from cortical to hippocampal to white matter domains in repeated $\mathrm{mTBI}$.

\section{Microglial Activation}

Microglia are spread throughout the brain parenchyma in their quiescent state and are the primary immune effector cells of the CNS. ${ }^{181}$ TBI-induced release of astrocytederived ATP triggers microglial recruitment. ${ }^{175}$ Microglia proliferate and infiltrate toward the injury site, phagocytosing necrotic tissue, cellular debris, and toxic substances, ${ }^{182}$ with the time course dependent upon the nature of injury. ${ }^{183}$ Also depending on the nature of the TBI, microglia upregulate cell surface marker expression, enhance pro-inflammatary cytokines (interleukin [IL]-1 $\beta$, IL-6, and TNF- $\alpha$ ) and oxidative metabolites (NO, ROS) release and increase protease secretion, thereby exacerbating oxidative stress, neuroinflammation, and axonal pathology. ${ }^{184}$ Sustained microglial activation and chronic inflammatory states contribute significantly to the spread of secondary degeneration, ${ }^{185}$ playing a pivotal role in long-term and progressive axonal injury, neurodegeneration and neurological impairments ${ }^{155,180,182,186,187}$ via mechanisms that include lipid peroxidation and apoptosis. ${ }^{185,188}$ Indeed, there is increasing evidence of chronic microglial activation in the cortex, corpus callosum (CC), and thalamus up to $1 \mathrm{y}$ after injury following moderate-severe TBI. ${ }^{182}$ Alternatively, microglia can assume a reparative role by releasing anti-inflammatory cytokines such as IL-10 that inhibit proinflammatory functions. ${ }^{189}$ Numbers of microglia along the cell death (M1) and repair promoting (M2) phenotypic spectrum depend on TBI severity and kinetics of regulation. ${ }^{188,190}$

The "immunoexcitotoxicity" theory suggests an alternative to the traditional and functionally distinct M1-M2 phenotypic polarization. Microglia are said to move from their resting and ramified state to one, where they swell with proinflammatory cytokines, remaining "primed" for action in the absence of inflammatory resolution. ${ }^{191}$ With further triggers, microglia become increasingly aggressive in their pro-inflammatory cytokine and free radical release, propagating downstream cascades that exacerbate damage and deficits, resulting in increased vulnerability to subsequent stimuli. ${ }^{191}$ The immunoexcitotoxicity theory may therefore provide a potential mechanistic link between the progression of acute to chronic pathology following repeated mTBI.

\section{Microglial Activation Following Repeated mTBI}

Microgliosis has been observed predominantly in the $\mathrm{CC}$ in closed-head models of single and repeated mTBI. Mild microgliosis in the $\mathrm{CC}$ is seen in the first $2 \mathrm{wk}$ following a single $\mathrm{mTBI}^{53,57,75}$; longer-term outcomes were not assessed. However, 2 injuries delivered at 24-h intervals result in prominent acute microglial responses that persist in white matter until $7 \mathrm{wk} .{ }^{56}$ Interestingly, when 4 mTBIs are given, exacerbated microglial hypertrophy and increased immunoreactivity are observed at acute ${ }^{150}$ and subacute, ${ }^{57}$ but not chronic ${ }^{70}$ time points. No acute or subacute microglial inflammation is observed when inter-injury interval is 
increased to $48 \mathrm{~h}$ in both $\mathrm{CCI}^{150}$ and WD aluminum foil models. $^{72}$ In contrast, persisting microglial responses are described in more severe, albeit still mTBI. ${ }^{53,180}$

\section{Diffuse Axonal Injury (DAI)}

DAI is a hallmark of TBI of all severities, in part due to anisotropically arranged axonal projections in white matter tracts being particularly susceptible to compression, tension, and torsion forces during rapid acceleration/ deceleration. ${ }^{109,192-194}$ The degree of axonal injury is dependent on injury severity ${ }^{195}$ and correlated with the plane of mechanical loading and decelerating force. ${ }^{192}$ Diffuse axonal injury is typically characterized by axonal stretching, mitochondrial swelling, and transport dysfunction. ${ }^{193}$ In moderate-severe TBI, the mechanical loading induces focal perturbations in the axolemma ${ }^{196}$ that can disrupt voltage-gated sodium $\left(\mathrm{Na}^{+}\right)$channels, reverse the $\mathrm{Na}^{+} / \mathrm{Ca}^{2+}$ exchanger, open voltage-gated $\mathrm{Ca}^{2+}$ channels, and facilitate excessive $\mathrm{Ca}^{2+}$ influx. ${ }^{197}$ Secondary messenger cascades activate protein kinases, phospholipases, and proteases, which within $6 \mathrm{~h}$ leads to either neurofilament instability via phosphorylation or neurofilament collapse via calpain-mediated proteolysis of side-arms. ${ }^{198} \mathrm{Ca}^{2+}$-mediated microtubule disassembly ensues, ${ }^{199}$ and cytoskeletal disorganization often persists, ${ }^{200}$ with silver staining used to visualize the punctate structures and argyrophilic fibers that are observed. Proteins accumulate, leading to multifocal axonal swellings that hinder axonal transport, ${ }^{201}$ often detected as accumulations of amyloid precursor protein (APP) ${ }^{202}$ Protein accumulation can initiate downstream cascades associated with secondary disconnection of the axon cylinder. ${ }^{197}$ While the detached distal segment undergoes Wallerian degeneration, the proximal axonal segment and associated neuronal soma of origin swells, but does not necessarily die. ${ }^{203}$ In contrast, ionic restoration can lead to axonal recovery, ${ }^{204}$ while a host of secondary injury mechanisms likely contribute to progressive axonal degeneration. ${ }^{200,205}$ Hyperphosphorylation of tau also occurs in $\mathrm{TBI},{ }^{206}$ resulting in reduced microtubule binding, ${ }^{207}$ which causes disassembly of microtubules and thus impaired axonal transport, leading to compromised neuronal and synaptic function. ${ }^{208}$ Increased tau aggregation into insoluble fibrils and larger aggregates in the form of insoluble fibrils, tangles, and neuropil threads are also observed ${ }^{209}$ and have been associated with subsequent neurodegenerative disease. $^{27}$

\section{Diffuse Axonal Injury Following Repeated mTBI}

DAI is considered to be a key feature of pathology following $\mathrm{mTBI}^{210}$ and is typically exacerbated with repeated injury. ${ }^{54,211}$ Repeated mTBI in adult mice worsens diffuse axonal injury and cognitive function with inter-injury intervals of 1-5, but not 7 d. ${ }^{150,151,212}$ Reducing the inter-injury interval to hours rather than days results in axonal injury, providing the injury severity is not sub-threshold. ${ }^{211}$ Similarly, motor function and spatial learning deficits, as well as increases in cytoskeletal damage and axonal injury indicated by increased APP, are more prominent in animals with repeated mTBI separated by $3 \mathrm{~d}$ than following single mTBI or a $7 \mathrm{~d}$ inter-injury interval. ${ }^{212}$ Following $2 \mathrm{CCI}$ mTBIs given $24 \mathrm{~h}$ apart, increases in APP develop subacutely, subsiding by $56 \mathrm{~d} .{ }^{54}$ Further, 5 repeated CCI mTBIs, with a 48 -h inter-injury interval, also result in increased APPimmunoreactive axonal profiles in the $\mathrm{CC}^{53}$ that persist chronically. ${ }^{180}$ Increases in microtubule-associated protein2 are observed following 2 mTBIs with a 24-h inter-injury interval, persisting chronically. ${ }^{151}$ However, no chronic axonal pathology is observed following 5 closed-head mTBIs delivered using the Kimwipe model at 24 -h or 1-wk intervals, despite persisting cognitive deficits. ${ }^{70,71}$

Axonal degeneration detected by silver staining has been observed following 4 CCI mTBIs given at 24-h intervals, acutely ${ }^{213}$ and subacutely. ${ }^{57}$ Further, acute cytoskeletal abnormalities and intra-axonal organelle compaction detected by ultrastructural analysis, that persist long-term in white matter tracts, is temporospatially coincident with a prominent microglial response following $2 \mathrm{CCI}$ mTBIs,${ }^{56}$ with similar outcomes in a model featuring rotational acceleration. ${ }^{75}$ Activated microglia form extended cytoplasmic processes in direct contact with injured axons to form a potential barrier between the healthy and injured tissue, suggesting that microglial activation is a response to the axonal damage. ${ }^{56,175}$

Phosphorylated tau and $A \beta$ have been explored in repeated mTBI studies, ${ }^{54,72,151}$ particularly using transgenic animal models, ${ }^{132,214,215}$ given their associations with CTE. ${ }^{26,216}$ Although repeated mTBI is thought to exacerbate secondary injury mechanisms that accelerate the development of chronic neurodegenerative diseases, the mechanistic link between repeated mTBI and CTE pathobiology is yet to be elucidated, and further prospective and longitudinal studies are required. ${ }^{28}$ Indeed, cognitive deficits after repeated mTBI can occur in the absence of increased tau phosphorylation or $\mathrm{A} \beta{ }^{70}$ and transgenic studies of specific tau isoforms indicate further complexities. ${ }^{217}$ Table 1 provides further information on studies assessing CTE-like pathology in repeated mTBI.

\section{Dysmyelination}

While axons and myelin forming fiber tracts are consanguineous, it is suggested that their pathologies following TBI are distinct, ${ }^{147,218}$ although studies exploring TBI-induced myelin pathology are relatively limited. Demyelination can occur as a result of several mechanisms, including primary axonal damage and subsequent Wallerian degeneration, or death of myelinating cells. Subacute loss of myelinated axons ${ }^{171,219}$ and myelin decompaction and redundancy ${ }^{218}$ have been reported following moderate TBI in rats. In contrast, transient subacute axonal dysfunction has been 
observed in the absence of myelin abnormalities, following moderate TBI (referred to as mild in the literature). ${ }^{220-222}$

Oligodendrocytes produce large amounts of $\operatorname{ROS}^{223,224}$ and have low antioxidant capacity. ${ }^{225}$ Indeed, oligodendrocytes, oligodendrocyte progenitor cells (OPCs), and myelin are particularly sensitive to glutamate excitotoxicity, $\mathrm{Ca}^{2+}$ overload, oxidative stress, and altered metabolism that occur following neurotrauma, ${ }^{226-228}$ with sensitivity thought to be maturation dependent. ${ }^{229}$ Extensive and sustained calpain-mediated degradation of myelin basic protein was reported in a moderate CCI TBI model, with intact proteins returning to baseline levels $3-5 \mathrm{~d}$ after injury. ${ }^{171}$ Additionally, myelin debris can stimulate inflammatory cells, and activated microglia and astrocytes can likewise promote myelin phagocytosis via ROS release ${ }^{230}$ and activate OPC recruitment. ${ }^{231}$ OPCs can rapidly respond to white matter injury and produce matrix metallopeptidase 9 that appears to open the BBB and trigger secondary cascades of cerebrovascular injury and demyelination. ${ }^{159,169}$ Indeed, perturbations in the BBB are known to be a critical part of white matter pathology in a wide range of CNS disorders. $^{232}$ However, transient upregulation of mature oligodendrocyte genes by $\mathrm{OPCs}^{147}$ as well as localization of OPCs to brain regions exhibiting neuronal damage ${ }^{170}$ suggests an acute regenerative response. Nevertheless, dysmyelination and demyelination persist and progress up to 1 y following injury, ${ }^{233}$ occurring simultaneously with prolonged reactive microgliosis and astrogliosis, ${ }^{147,234}$ indicating ongoing stimulation by myelin debris.

\section{Dysmyelination Following Repeated mTBI}

Studies exploring myelin abnormalities in animal models of repeated mTBI are scant. Subcortical white matter tract damage is seen in single $\mathrm{mTBI}^{54,212,221,235,236}$ and a longterm experimental study of mTBI using both single and repeated injuries reported $\mathrm{CC}$ thinning accompanied by neurological deficits $1 \mathrm{y}$ following injury. ${ }^{180}$ Progressive myelin pathology has been indicated by decreased radial diffusivity $^{55}$ and double concentric myelin sheaths ${ }^{56}$ following 2 CCI mTBIs delivered at a 24-h interval. More persistent and severe myelin pathology with evidence of remyelination was observed with a repeated "mild" TBI; however, acute focal lesions and blood deposition suggest the injury was of moderate severity. ${ }^{51}$ These findings likely reflect cognitive and behavioral dysfunction following $\mathrm{mTBI}^{237,238}$; however, behavioral assessments in these studies were lacking. Further studies assessing the effects of injury interval, number and severity on chronic myelin pathology together with behavior are warranted.

\section{Behavioral Deficits Following Repeated mTBI}

The most commonly used assessments to determine longterm behavioral outcome in TBIs include neurological severity tests to assess gross motor deficits; beam walking and rotarod performance which assess sensory, motor, and sensorimotor domains; and various MWM paradigms to assess learning and memory as a correlate to cognitive function. ${ }^{239}$ Tests assessing psychological sequelae have also been employed to detect anxiety- and depressivelike behavior. Behavioral impairments have been consistently revealed in closed-head animal models of repeated $\mathrm{mTBI}$, incorporating various degrees of head movement and inter-injury intervals. Mice sustaining 2 mTBIs at 24-h intervals had acute learning and memory deficits in $\mathrm{MWM}^{56}$ and Barnes maze performance ${ }^{75}$ that persisted to subacute time points. However, variability exists between studies of similar design, with some animals exhibiting longer-term balance deficits in the absence of persisting cognitive impairments. ${ }^{54}$ When total injury numbers are increased to 5 , transient balance and motor coordination deficits in the rotarod test are described, while locomotor hyperactivity persists to 1 mo. $^{72}$ In similar studies, measurable cognitive deficits persist beyond 3 mo. ${ }^{57,71,151}$ As such, when repeated mTBIs are delivered within the "window of vulnerability" (described in Mechanisms of Pathology section), cumulative cognitive deficits persist and may be permanent. ${ }^{54,65,71}$ Interestingly, longer inter-injury intervals up to 1 mo produce no deficits, ${ }^{68,71}$ suggesting that longer time intervals may confer protection against subacute $^{212}$ and long-term functional sequelae. ${ }^{70}$ Additionally, studies titrating mechanical input have revealed a threshold of injury severity required to elicit deficits. ${ }^{56,65}$ Thus, it appears that behavioral deficits significantly associate with the number of mTBIs, inter-injury interval, and severity of impact.

\section{Toward Clinical Management of Repeated mTBI}

Pharmacological therapies for TBI in humans are lacking. ${ }^{83}$ Therapeutic strategies in development are targeted toward secondary injury pathways that are potentially modifiable and therefore amenable to treatment ${ }^{43}$ and are generally focused on facilitating neuroprotection or inhibiting neurotoxicity. Given the subtle acute pathology following mTBI, treatment options for repeated mTBIs hinge on decreasing the progression of secondary damage and improving longterm functional outcomes. As described above, the first injury appears to place the brain in a vulnerable metabolic state. Therefore, appropriate immediate treatment following a single mTBI may facilitate acute physiological recovery and reduce the potential for cumulative damage with further injury. Further, treatments administered beyond the acute time point may be useful for targeting specific elements of secondary degeneration. However, a greater understanding of the mechanisms of damage following repeated mTBI is likely to be required to facilitate effective development of therapeutics as well as inform return to play guidelines. 


\section{Therapeutic Strategies for Repeated mTBI}

Preclinical studies assessing efficacy of therapeutics for repeated mTBI have been reported, and current targets focus specifically on reducing inflammation, oxidative stress, axonal injury, and associated neurodegenerative-like pathology. Targeting microglial activation via anti-CD $11 \mathrm{~d},{ }^{47}$ progesterone, ${ }^{240}$ and Valganciclovir ${ }^{213}$ to ameliorate the inflammatory response following repeated $\mathrm{mTBI}$ has shown some promise. Rats given 3 mild LFP injuries at a $5 \mathrm{~d}$ interinjury interval, and treated with anti-CD11d antibody, exhibit reduced neutrophil and macrophage infiltration, lipid peroxidation, astrocyte activation, APP accumulation and neuronal loss, concomitant with improved performance on cognitive, sensorimotor, and anxiety tasks, relative to controls. ${ }^{47}$ Using a similar study design, the steroid hormone progesterone decreases lipid peroxidation and microglial and astrocytic markers of neuroinflammation, while long-term cognitive and sensorimotor outcomes are improved. ${ }^{240}$ For both of these studies however, acute damage and deficits were potentially dampened given the $5 \mathrm{~d}$ inter-injury interval. Valganciclovir-induced macrophage depletion decreases the microglial population in the $\mathrm{CC}$ and external capsule, as expected, but doesn't alter the extent of acute axonal injury after 2 CCI mTBIs at 24-h intervals. ${ }^{213}$

Rosemary extract ( $20 \%$ carnosic acid) administered following 3 mTBIs at a 24-h inter-injury interval reduces astrocytosis, oxidative stress, inflammatory cytokines, and degenerating neurons in the hippocampus and restores cognitive deficits. ${ }^{78}$ However, significant numbers of degenerating neurons in the hippocampus following the repeated mTBI suggest that a more severe injury was induced. The immunosuppressant FK506 (Tacrolimus) or moderate hypothermia $\left(32-33^{\circ} \mathrm{C}\right.$ for $\left.1 \mathrm{~h}\right)$ following 2 impactacceleration mTBIs at a 3-h inter-injury interval significantly attenuates axonal and cerebral microvascular changes by inhibiting calcineurin, free-radical and metabolically mediated cascades. ${ }^{241}$ Following 2 closed-head mTBIs incorporating rotational acceleration, given on consecutive days, the liver X receptor agonist GW3965 improves cognition, axonal integrity, and $\mathrm{A} \beta$ clearance in an Apolipoprotein E (ApoE)-dependent manner. ${ }^{67}$

Preventing tauopathy or decreasing the risk of developing neurodegenerative disease has been attempted using various models and treatment targets. Vitamin E, a potent exogenous antioxidant, was administered for $12 \mathrm{wk}$ to aged transgenic mice, exhibiting Alzheimer's disease-like amyloidosis. Prevention of A $\beta$ peptide accumulation and reduction in brain lipid peroxidation and behavioral deficits following 2 CCI mTBIs ${ }^{133}$ suggest antioxidants may reduce the putative risk of repeated mTBI-associated Alzheimer's disease. Following 3 closed-head CCI mTBIs given at 24-h intervals, inhibition of monoacylglycerol lipase, an endocannabinoid 2-arachidonoylglycerol metabolizing enzyme, significantly reduces CTE-like neuropathological changes, proinflammatory cytokines, astroglial reactivity, and cognitive deficits. ${ }^{242}$ Additionally, using transgenic and knockout tau mice in a Kimwipe mTBI model, cis p-tau antibody treatment prevents the temporospatial progression of tauopathy and cognitive decline by blocking axonal microtubule and mitochondrial disruptions. ${ }^{243}$ Finally, sodium selenate treatment of 3 LFP mTBIs at a $5 \mathrm{~d}$ interinjury interval results in tau dephosphorylation and ameliorates cognitive decline via protein phosphatase $2 \mathrm{~A} 55 \mathrm{kDa}$ regulatory B subunit upregulation. ${ }^{244}$

Effects of pre-treatment of repeated mTBIs using fish oil $^{245}$ and androgenic steroids ${ }^{246}$ have also been explored. Rat chow enhanced with $6 \%$ omega- 3 fatty acids was provided for $4 \mathrm{wk}$ prior and $2 \mathrm{wk}$ following 2 LFP mTBIs at a 24-h inter-injury interval; recovery of body weight was improved, with a trend toward increases in hippocampal neurons and cognitive performance. ${ }^{245}$ Interestingly, a combination of testosterone, nandrolone, and $17 \alpha$-methyl testosterone increases axonal injury and microgliosis, ${ }^{246}$ suggesting athletes who use these agents may suffer from detrimental effects following mTBI.

\section{Barriers to Clinical Translation}

While swine ${ }^{247,248}$ and cell culture approaches ${ }^{249,250}$ have recently been used to model repeated mTBI, the majority of studies use rodents. There are, however, inherent structural and behavioral differences in rodents that challenge the emulation of human mTBI, in terms of mechanical input, and structural and behavioral output. Mass, white to gray matter proportions, cerebral convolutions, presence of cerebrospinal fluid and craniospinal angle influence the nature of TBI-induced tissue strain. ${ }^{201}$ Choosing the intervals between injuries in experimental models is confounded by difficulties relating rat age to humans, ${ }^{251}$ which is important when determining return to play time frames following sports-related mTBI. Additionally, strain-dependent behavioral and histological responses have been revealed in rodents. ${ }^{252}$ Further, studies using non-transgenic female rodents are lacking. While acute neuroprotective effects of oestrogen have been suggested in a rodent WD impact-acceleration model, ${ }^{253}$ exacerbated outcomes following repeated mTBIs in female soccer players indicate complexities. ${ }^{254}$ Finally, pediatric populations exhibit different responses to adults experiencing a similar head trauma, ${ }^{255}$ and limited studies have been conducted assessing younger populations. ${ }^{235,236,256,257}$

\section{Conclusions}

Long-term cognitive impairments following CNS injury and in neurodegenerative diseases have been associated with prolonged oxidative stress conditions ${ }^{131,258}$ and impaired signal conduction along dysmyelinated axons. ${ }^{259}$ Further, persisting behavioral deficits after TBI have been associated with progressive activation of astrocytes ${ }^{260}$ and microglia. ${ }^{261}$ While mild and repeated mTBI can impair long-term function, ${ }^{262}$ studies are yet to simultaneously 
measure behavioral, oxidative, neuroinflammatory, and myelin integrity outcomes at acute and chronic phases. As such, key mechanistic insights needed to design therapies tailored to limit chronic deficits following repeated mTBI are lacking. Therapies designed to stabilize and improve metabolic status in the acute time period after injury may protect neurons and glia, translating to significant improvements in long-term functional outcome. As more is learned about BBB regulation following repeated mTBI, further opportunities may emerge to target the brain endothelium to maintain health and facilitate recovery. Diffuse axonal injury and white-matter damage is increasingly understood to underlie progression of cognitive impairments and better understanding of myelin pathology using both advanced imaging and ultrastructural analyses following repeated mTBI will also likely contribute to improved therapeutic opportunities. While elucidating the mechanisms of damage underlying cell dysfunction following repeated mTBI is crucial to develop therapeutic strategies, it is also important to appreciate cell regenerative processes known to occur in moderate-severe TBI. ${ }^{263}$ The hippocampus is implicated in persisting memory deficits following repeated mTBI and complex forms of hippocampalmediated learning require adult-born neurons. ${ }^{264}$ Following repeated LFP mTBI, long-term potentiation deficits and failed $N$-methyl-D-aspartate-receptor-mediated hippocampal synaptic excitation suggest a lack of adaptive plasticity. ${ }^{45}$ Therefore, therapeutic strategies designed to enhance neurogenesis and functional plasticity following repeated mTBI may also be required.

\section{Authors' Contribution}

Brooke Fehily researched and wrote the manuscript. Melinda Fitzgerald edited and critically evaluated the manuscript. Both authors read and approved the final manuscript.

\section{Statement of Informed Consent}

There are no human subjects in this article, and informed consent is not applicable.

\section{Declaration of Conflicting Interests}

The author(s) declared no potential conflicts of interest with respect to the research, authorship, and/or publication of this article.

\section{Funding}

The author(s) disclosed receipt of the following financial support for the research and/or authorship of this article: Melinda Fitzgerald is supported by an NHMRC Career Development Fellowship (APP1087114).

\section{References}

1. McCrory P, Meeuwisse WH, Aubry M, Cantu B, Dvořák J, Echemendia RJ, Engebretsen L, Johnston K, Kutcher JS, Raftery $\mathrm{M}$, et al. Consensus statement on concussion in sport: the 4th international conference on concussion in sport held in
Zurich, November 2012. Br J Sports Med. 2013;47(5): 250-258.

2. Langlois JA, Rutland-Brown W, Wald MM. The epidemiology and impact of traumatic brain injury. J Head Trauma Rehabil. 2006;21(5):375-378.

3. Werner C, Engelhard K. Pathophysiology of traumatic brain injury. Br J Anaesth. 2007;99(1):4-9.

4. Plassman BL, Havlik RJ, Steffens DC, Helms MJ, Newman TN, Drosdick D, Phillips C, Gau BA, Welsh-Bohmer KA, Burke JR, et al. Documented head injury in early adulthood and risk of Alzheimer's disease and other dementias. Neurology. 2000;55(8):1158-1166.

5. Corrigan JD, Hammond FM. Traumatic brain injury as a chronic health condition. Arch Phys Med Rehabil. 2013; 94(6):1199-1201.

6. Maas AIR, Stocchetti N, Bullock R. Moderate and severe traumatic brain injury in adults. Lancet Neurol. 2008;7(8): 728-741.

7. Teasdale G, Jennett B. Assessment of coma and impaired consciousness. A practical scale. Lancet. 1974;2(7872):81-84.

8. Marshall LF, Marshall SB, Klauber MR, Van Berkum Clark M, Eisenberg HM, Jane JA, Luerssen TG, Marmarou A, Foulkes MA. A new classification of head injury based on computerized tomography. J Neurosurg. 1991;75(1S):S14-S20.

9. Masson F, Thicoipe M, Aye P, Mokni T, Senjean P, Schmitt V, Dessalles P-H, Cazaugade M, Labadens P. Epidemiology of severe brain injuries: a prospective population-based study. J Trauma. 2001;51(3):481-489.

10. Blyth BJ, Bazarian JJ. Traumatic alterations in consciousness: traumatic brain injury. Emerg Med Clin North Am. 2010; 28(3):571-594.

11. McCrory P, Meeuwisse W, Johnston K, Dvorak J, Aubry M, Molloy M, Cantu R. Consensus statement on concussion in sport - the 3rd international conference on concussion in sport held in zurich, november 2008. J Sci Med Sport. 2009;12(3): 340-351.

12. Cassidy J, Carroll L, Peloso P, Borg J, von Holst H, Holm L, Kraus J, Coronado V. Incidence, risk factors and prevention of mild traumatic brain injury: results of the WHO collaborating centre task force on mild traumatic brain injury. J Rehabil Med. 2004;43(Suppl):28-60.

13. Vanderploeg RD, Belanger HG, Horner RD, Spehar AM, Powell-Cope G, Luther SL, Scott SG. Health outcomes associated with military deployment: mild traumatic brain injury, blast, trauma, and combat associations in the florida national guard. Arch Phys Med Rehabil. 2012;93(11):1887-1895.

14. Holbourn AHS. Mechanics of head injury. Lancet. 1943; 242(6267):438-441.

15. Dashnaw ML, Petraglia AL, Bailes JE. An overview of the basic science of concussion and subconcussion: where we are and where we are going. Neurosurg Focus. 2012;33(6):E5:1-9.

16. Meaney DF, Smith DH. Biomechanics of concussion. Clin in Sports Med. 2011;30(1):19-31.

17. Carroll LJ, Cassidy JD, Holm L, Kraus J, Coronado VG. Methodological issues and research recommendations for mild traumatic brain injury: the WHO collaborating centre task force on 
mild traumatic brain injury. J Rehab Med. 2004;43(Suppl): $113-125$.

18. Rivara FP, Graham R. Sports-related concussions in youth: report from the institute of medicine and national research council. JAMA. 2014;311(3):239-240.

19. Binder L, Rohling M, Larrabee G. A review of mild head trauma. Part I: meta-analytic review of neuropsychological studies. J Clin Exp Neuropsychol. 1997;19(3):421-431.

20. Willer B, Leddy JJ. Management of concussion and postconcussion syndrome. Curr Treat Options Neurol. 2006;8(5): 415-526.

21. Mittenberg W, Canyock EM, Condit D, Patton C. Treatment of post-concussion syndrome following mild head injury. J Clin Exp Neuropsychol. 2001;23(6):829-836.

22. Kraus MF, Susmaras T, Caughlin BP, Walker CJ, Sweeney JA, Little DM. White matter integrity and cognition in chronic traumatic brain injury: a diffusion tensor imaging study. Brain. 2007;130(10):2508-2519.

23. Belanger HG, Spiegel E, Vanderploeg RD. Neuropsychological performance following a history of multiple self- reported concussions: a meta-analysis. J Int Neuropsychol Soc. 2010; 16(2):262-267.

24. Geddes JF, Vowles GH, Nicoll JAR, Révész T. Neuronal cytoskeletal changes are an early consequence of repetitive head injury. Acta Neuropathol. 1999;98(2):171-178.

25. Guskiewicz KM, Marshall SW, Bailes J, McCrea M, Cantu RC, Randolph C, Jordan BD. Association between recurrent concussion and late-life cognitive impairment in retired professional football players. Neurosurgery. 2005;57(4): 719-726.

26. McKee AC, Stein TD, Nowinski CJ, Stern RA, Daneshvar DH, Alvarez VE, Lee H-S, Hall G, Wojtowicz SM, Baugh CM, et al. The spectrum of disease in chronic traumatic encephalopathy. Brain. 2013;136(1):43-64.

27. Baugh CM, Robbins CA, Stern RA, McKee AC. Current understanding of chronic traumatic encephalopathy. Curr Treat Options Neurol. 2014;16(9):306.

28. McCrory P, Meeuwisse W, Kutcher JS, Jordan BD, Gardner A. What is the evidence for chronic concussion-related changes in retired athletes: behavioural, pathological and clinical outcomes? Br J Sports Med. 2013;47(5):327-330.

29. Dewitt DS, Perez-Polo R, Hulsebosch CE, Dash PK, Robertson CS. Challenges in the development of rodent models of mild traumatic brain injury. J Neurotrauma. 2013;30(9): 688-701.

30. Xiong Y, Mahmood A, Chopp M. Animal models of traumatic brain injury. Nat Rev Neurosci. 2013;14(2):128-142.

31. Angoa-Pérez M, Kane MJ, Briggs DI, Herrera-Mundo N, Viano DC, Kuhn DM. Animal models of sports-related head injury: bridging the gap between pre-clinical research and clinical reality. J Neurochem. 2014;129(6):916-931.

32. Laplaca MC, Simon CM, Prado GR, Cullen DK. CNS injury biomechanics and experimental models. Prog Brain Res. 2007; 161:13-26.

33. Namjoshi DR, Good C, Cheng WH, Panenka W, Richards D, Cripton PA, Wellington CL. Towards clinical management of traumatic brain injury: a review of models and mechanisms from a biomechanical perspective. Dis Models Mech. 2013; 6(6):1325-1338.

34. Zhang L, Yang KH, King AI. A proposed injury threshold for mild traumatic brain injury. J Biomech Engin. 2004;126(2): 226-236.

35. Cole JT, Yarnell A, Kean WS, Gold E, Lewis B, Ren M, McMullen DC, Jacobowitz DM, Pollard HB, O’Neill JT, et al. Craniotomy: true sham for traumatic brain injury, or a sham of a sham? J Neurotrauma. 2011;28(3):359-369.

36. Statler KD, Alexander H, Vagni V, Dixon CE, Clark RSB, Jenkins L, Kochanek PM. Comparison of seven anesthetic agents on outcome after experimental traumatic brain injury in adult, male rats. J Neurotrauma. 2006;23(1): 97-108.

37. Dixon CE, Lyeth BG, Povlishock JT, Findling RL, Hamm RJ, Marmarou A, Young HF, Hayes RL. A fluid percussion model of experimental brain injury in the rat. J Neurosurg. 1987; 67(1):110-119.

38. Lighthall JW. Controlled cortical impact: a new experimental brain injury model. J Neurotrauma. 1988;5(1):1-15.

39. Floyd CL, Golden KM, Black RT, Hamm RJ, Lyeth BG. Craniectomy position affects morris water maze performance and hippocampal cell loss after parasagittal fluid percussion. J Neurotrauma. 2002;19(3):303-316.

40. McIntosh TK, Vink R, Noble L, Yamakami I, Fernyak S, Soares H, Faden AL. Traumatic brain injury in the rat: characterization of a lateral fluid-percussion model. Neuroscience. 1989;28(1):233-244.

41. Kabadi SV, Hilton GD, Stoica BA, Zapple DN, Faden AI. Fluid-percussion-induced traumatic brain injury model in rats. Nat Protoc. 2010;5(9):1552-1563.

42. Thompson HJ, Lifshitz J, Marklund N, Grady MS, Graham DI, Hovda DA, McIntosh TK. Lateral fluid percussion brain injury: a 15-year review and evaluation. J Neurotrauma. 2005;22:42-75.

43. Graham DI, McIntosh TK, Maxwell WL, Nicholl JAR. Recent advances in neurotrauma. J Neuropathol Exp Neurol. 2000; 59(8):641-651.

44. Raghupathi R, Conti AC, Graham DI, Krajewski S, Reed JC, Grady MS, Trojanoswki JQ, McIntosh TK. Mild traumatic brain injury induces cell death in the cortex that is preceded by decreases in cellular bcl-2 immunoreactivity. Neuroscience. 2002;110(4):605-616.

45. Aungst SL, Kabadi SV, Thompson SM, Stoica BA, Faden AI. Repeated mild traumatic brain injury causes chronic neuroinflammation, changes in hippocampal synaptic plasticity, and associated cognitive deficits. J Cereb Blood Flow Metab. 2014; 34(7):1223-1232.

46. Shultz SR, Bao F, Omana V, Chiu C, Brown A, Cain DP. Repeated mild lateral fluid percussion brain injury in the rat causes cumulative long-term behavioral impairments, neuroinflammation, and cortical loss in an animal model of repeated concussion. J Neurotrauma. 2012;29(2):281-294.

47. Shultz SR, Bao F, Weaver L, Cain D, Brown A. Treatment with an anti-CD11d integrin antibody reduces neuroinflammation 
and improves outcome in a rat model of repeated concussion. $\mathrm{J}$ Neuroinflammation. 2013;10(1):26.

48. Hall ED, Sullivan PG, Gibson TR, Pavel KM, Thompson BM, Scheff SW. Spatial and temporal characteristics of neurodegeneration after controlled cortical impat in mice: more than a focal brain injury. J Neurotrauma. 2005;22(2):252-265.

49. Lighthall JW, Goshgarian HG, Pinderski CR. Characterization of axonal injury produced by controlled cortical impact. J Neurotrauma. 1990;7(2):65-76.

50. Donovan V, Bianchi A, Hartman R, Bhanu B, Carson MJ, Obenaus A. Computational analysis reveals increased blood deposition following repeated mild traumatic brain injury. NeuroImage Clin. 2012;1(1):18-28.

51. Donovan V, Kim C, Anugerah AK, Coats JS, Oyoyo U, Pardo $\mathrm{AC}$, Obenaus A. Repeated mild traumatic brain injury results in long-term white-matter disruption. J Cereb Blood Flow Metab. 2014;34(4):715-723.

52. Huang L, Coats JS, Mohd-Yusof A, Yin Y, Assaad S, Muellner MJ, Kamper JE, Hartman RE, Dulcich M, Donovan VM, et al. Tissue vulnerability is increased following repetitive mild traumatic brain injury in the rat. Brain Res. 2013; 1499:109-120.

53. Mouzon B, Chaytow H, Crynen G, Bachmeier C, Stewart J, Mullan M, Stewart W, Crawford F. Repetitive mild traumatic brain injury in a mouse model produces learning and memory deficits accompanied by histological changes. J Neurotrauma. 2012;29(18):2761-2773.

54. Laurer HL, Bareyre FM, Lee VMYC, Trojanowski JQ, Longhi L, Hoover R, Saatman KE, Raghupathi R, Hoshino S, Grady MS, et al. Mild head injury increasing the brain's vulnerability to a second concussive impact. J Neurosurg. 2001;95(5): 859-870.

55. Bennett RE, Mac Donald CL, Brody DL. Diffusion tensor imaging detects axonal injury in a mouse model of repetitive closed-skull traumatic brain injury. Neurosci Lett. 2012; 513(2):160-165.

56. Shitaka Y, Tran HT, Bennett RE, Sanchez L, Levy MA, Dikranian K, Brody DL. Repetitive closed-skull traumatic brain injury in mice causes persistent multifocal axonal injury and microglial reactivity. J Neuropathol Exp Neurol. 2011;70(7): 551-567.

57. Hylin MJ, Orsi SA, Rozas NS, Hill JL, Zhao J, Redell JB, Moore AN, Dash PK. Repeated mild closed head injury impairs short-term visuospatial memory and complex learning. J Neurotrauma. 2013;30(9):716-726.

58. Petraglia AL, Plog B, Dayawansa S, Chen MJ, Dashnaw ML, Czerniecka K, Walker CJ, Viterise T, Hyrien O, Iliff JJ, et al. The spectrum of neurobehavioral sequelae after repetitive mild traumatic brain injury: a novel mouse model of chronic traumatic encephalopathy. J Neurotrauma. 2014;31(13): $1211-1224$.

59. Petraglia AL, Plog BA, Dayawansa S, Dashnaw ML, Czerniecka K, Walker CT, Chen M, Hyrien O, Iliff JJ, Deane R, et al. The pathophysiology underlying repetitive mild traumatic brain injury in a novel mouse model of chronic traumatic encephalopathy. Surg Neurol Int. 2014;5:184.
60. Feeney DM, Boyeson MG, Linn RT, Murray HM, Dail WG. Responses to cortical injury: I. Methodology and local effects of contusions in the rat. Brain Res. 1981;211(1):67-77.

61. Chen Y, Constantini S, Trembovler V, Weinstock M, Shohami E. An experimental model of closed head injury in mice: pathophysiology, histopathology, and cognitive deficits. J Neurotrauma. 1996;13(10):557-568.

62. Shapira Y, Shohami E, Sidi A, Soffer D, Freeman S, Cotev S. Experimental closed head injury in rats: mechanical, pathophysiologic, and neurologic properties. Crit Care Med. 1989;16(3): 258-265.

63. Marmarou AM, Foda MAA-E, Van Den Brink W, Campbell J, Kita H, Demetriadou K. A new model of diffuse brain injury in rats. Part i: pathophysiology and biomechanics. J Neurosurg. 1994;80(2):291-300.

64. Foda MAA-E, Marmarou A. A new model of diffuse brain injury in rats. Part ii: morphological characterization. J Neurosurg. 1994;80(2):301-313.

65. Deford SM, Wilson MS, Rice AC, Clausen T, Rice LK, Barabnova A, Bullock R, Hamm RJ. Repeated mild brain injuries result in cognitive impairment in b6c3f1 mice. J Neurotrauma. 2002;19(4):427-438.

66. Creeley CE, Wozniak DF, Bayly PV, Olney JW, Lewis LM. Multiple episodes of mild traumatic brain injury result in impaired cognitive performance in mice. Acad Emerg Med. 2004;11(8):809-819.

67. Namjoshi DR, Martin G, Donkin J, Wilkinson A, Stukas S, Fan J, Carr M, Tabarestani S, Wuerth K, Hancock REW, et al. The liver x receptor agonist gw3965 improves recovery from mild repetitive traumatic brain injury in mice partly through apolipoprotein e. PLoS One. 2013;8(1):e53529.

68. Weil ZM, Gaier KR, Karelina K. Injury timing alters metabolic, inflammatory and functional outcomes following repeated mild traumatic brain injury. Neurobiol Dis. 2014;70: 108-16.

69. Vagnozzi R, Signoretti S, Tavazzi B, Cimatti M, Amorini AM, Donzelli S, Delfini R, Lazzarino G. Hypothesis of the postconcussive vulnerable brain: experimental evidence of its metabolic occurrence. Neurosurgery. 2005;57(1): 164-171.

70. Mannix R, Meehan WP, Mandeville J, Grant PE, Gray T, Berglass J, Zhang J, Bryant J, Rezaie S, Chung JY, et al. Clinical correlates in an experimental model of repetitive mild brain injury. Ann Neurol. 2013;74(1):65-75.

71. Meehan WP, Zhang J, Mannix R, Whalen MJ. Increasing recovery time between injuries improves cognitive outcome after repetitive mild concussive brain injuries in mice. Neurosurgery. 2012;71(4):885-892.

72. Kane MJ, Angoa-Pérez M, Briggs DI, Viano DC, Kreipke CW, Kuhn DM. A mouse model of human repetitive mild traumatic brain injury. J Neurosci Methods. 2012;203(1):41-49.

73. Levin HS, Robertson CS. Mild traumatic brain injury in translation. J Neurotrauma. 2013;30(8):610-617.

74. Acabchuk R, Briggs DI, Angoa-Pérez M, Powers M, Wolferz R Jr, Soloway M, Stern M, Talbot LR, Kuhn DM, Conover JC. Repeated mild traumatic brain injury causes focal response in 
lateral septum and hippocampus. Concussion. 2016;1(3). DOI: 10.2217/cnc-2015-0001.

75. Namjoshi DR, Cheng WH, McInnes KA, Martens KM, Carr M, Wilkinson A, Fan J, Robert J, Hayat A, Cripton PA, et al. Merging pathology with biomechanics using chimera (closed-head impact model of engineered rotational acceleration): a novel, surgery-free model of traumatic brain injury. Mol Neurodegen. 2014;9(1):55.

76. Cheng JS, Craft R, Yu G-Q, Ho K, Wang X, Mohan G, Mangnitsky S, Ponnusamy R, Mucke L. Tau reduction diminishes spatial learning and memory deficits after mild repetitive traumatic brain injury in mice. PLoS One. 2014;9(12):e115765.

77. Kilbourne M, Kuehn R, Tosun C, Caridi J, Keledjian K, Bochicchio G, Scalea T, Gerzanich V, Simard JM. Novel model of frontal impact closed head injury in the rat. J Neurotrauma. 2009;26(12):2233-2243.

78. Song H, Xu L, Zhang R, Cao Z, Zhang H, Yang L, Guo Z, Qu $\mathrm{Y}, \mathrm{Yu}$ J. Rosemary extract improves cognitive deficits in a rats model of repetitive mild traumatic brain injury associated with reduction of astrocytosis and neuronal degeneration in hippocampus. Neurosci Lett. 2016;622:95-101.

79. Yu J-Y, Li J-X, Guo Z-Y, Zhao X-L, Zhao X-D. [Coma criterion and classification standard of mild and moderate traumatic brain injury in rats]. Fa Yi Xue Za Zhi. 2008;24(1):8-11.

80. Bolouri H, Säljö A, Viano DC, Hamberger A. Animal model for sport-related concussion; ICP and cognitive function. Acta Neurol Scand. 2012;125(4):241-247.

81. Viano DC, Hamberger A, Bolouri H, Säljö A. Concussion in professional football: animal model of brain injury-part 15 . Neurosurgery. 2009;64(6):1162-1173.

82. Finan J, Elkin B, Pearson E, Kalbian I, Morrison B. Viscoelastic properties of the rat brain in the sagittal plane: effects of anatomical structure and age. Ann Biomed Eng. 2012;40(1): 70-78.

83. Loane DJ, Faden AI. Neuroprotection for traumatic brain injury: translational challenges and emerging therapeutic strategies. Trends Pharmacol Sci. 2010;31(12):596-604.

84. Iverson GL. Outcome from mild traumatic brain injury. Curr Opin Psychiatry. 2005;18(3):301-317.

85. Giza CC, Hovda AD. The new neurometabolic cascade of concussion. Neurosurgery. 2014;75(4): S24-S33.

86. Barkhoudarian G, Hovda DA, Giza CC. The molecular pathophysiology of concussive brain injury. Clin Sports Med. 2011; 30(1):33-48

87. Farkas O, Lifshitz J, Povlishock JT. Mechanoporation induced by diffuse traumatic brain injury: an irreversible or reversible response to injury. J Neurosci. 2006;26(12):3130-3140.

88. Katayama Y, Becker DP, Tamura T, Hovda DA. Massive increases in extracellular potassium and the indiscriminate release of glutamate following concussive brain injury. J Neurosurg. 1990;73(6):889-900.

89. Casson RJ. Possible role of excitotoxicity in the pathogenesis of glaucoma. Clin Exp Opthamol. 2006;34(1):54-63.

90. Chen SF, Richards HK, Smielewski P, Johnstrom P, Salvador R, Pickard JD, Harris NG. Relationship between flowmetabolism uncoupling and evolving axonal injury after experimental traumatic brain injury. J Cereb Blood Flow Metab. 2004;24(9):1025-1036.

91. Giza CC, Hovda DA. The neurometabolic cascade of concussion. J Athl Train. 2001;36(3):228-235.

92. Deshpande LS, Sun DA, Sombati S, Baranova A, Wilson MS, Attkisson E, Hamm RJ, DeLorenzo RJ. Alterations in neuronal calcium levels are associated with cognitive deficits after traumatic brain injury. Neurosci Lett. 2008;441(1):115-119.

93. Sullivan PG, Thompson MB, Scheff SW. Cyclosporin a attenuates acute mitochondrial dysfunction following traumatic brain injury. Exp Neurol. 1999;160(1):226-234.

94. Glenn TC, Kelly DF, Boscardin WJ, McArthur DL, Vespa P, Oertel M, Hovda DA, Bergsneider M, Hillered L, Martin NA. Energy dysfunction as a predictor of outcome after moderate or severe head injury: indices of oxygen, glucose, and lactate metabolism. J Cereb Blood Flow Metab. 2003;23(10): $1239-1250$

95. Tavazzi B, Signoretti S, Lazzarino G, Amorini AM, Delfini R, Cimatti M, Marmarou A, Vagnozzi R. Cerebral oxidative stress and depression of energy metabolism correlate with severity of diffuse brain injury in rats. Neurosurgery. 2005; 56(3):582-589.

96. Signoretti S, Marmarou A, Tavazzi B, Lazzarino G, Beaumont A, Vagnozzi R. N-acetylaspartate reduction as a measure of injury severity and mitochondrial dysfunction following diffuse traumatic brain injury. J Neurotrauma. 2001;18(10):977-991.

97. Richards HK, Simac S, Piechnik S, Pickard JD. Uncoupling of cerebral blood flow and metabolism after cerebral contusion in the rat. J Cereb Blood Flow Metab. 2001;21(7):779-781.

98. Ginsberg MD, Zhao W, Alonso OF, Loor-Estades JY, Dietrich WD, Busto R. Uncoupling of local cerebral glucose metabolism and blood flow after acute fluid-percussion injury in rats. Am J Physiol. 1997;272(6):H2859-H2868.

99. Giri BK, Krishnappa IK, Bryan RM, Roberts C. Regional cerebral blood flow after cortical impact injury complicated by a secondary insult in rats. Stroke. 2000;31(4):961-967.

100. Andersen BJ, Marmarou A. Functional compartmentalization of energy production in neural tissue. Brain Res. 1992;585(1): 190-195.

101. Yoshino A, Hovda DA, Kawamata T, Katayama Y, Becker DP. Dynamic changes in local cerebral glucose utilization following cerebral concussion in rats: evidence of a hyperand subsequent hypometabolic state. Brain Res. 1991;561(1): $106-119$

102. Hovda DA. Long-term changes in metabolic rates for glucose following mild, moderate and severe concussive head injuries in adult rats. J Neurosurgery. 1994;376:1995.

103. Moore AN, Osteen CL, Chatziioanno AF, Hovda DA, Cherry SR. Quantitative assessment of longitudinal metabolic changes in vivo after traumatic brain injury in the adult rat using fdg-micropet. J Cereb Blood Flow Metab. 2000;20(10): $1492-1501$

104. Cherian L, Roberson CS, Goodman JC. Secondary insults increase injury after controlled cortical impact in rats. J Neurotrauma. 1996;13(7):371-383. 
105. Jenkins LW, Moszynski K, Lyeth BG, Lewelt W, Dewitt DS, Allen A, Dixon CE, Povlishock JT, Majewski TJ, Clifton GL, et al. Increased vulnerability of the mildly traumatized rat brain to cerebral ischemia: the use of controlled secondary ischemia as a research tool to identify common or different mechanisms contributing to mechanical and ischemic brain injury. Brain Res. 1989;477(1-2):211-224.

106. Steifel MF, Tomita Y, Marmarou A. Secondary ischemia impairing the restoration of ion homeostasis following traumatic brain injury. J Neurosurg. 2005;103(4):707-714.

107. Vagnozzi R, Tavazzi B, Signoretti S, Amorini AM, Belli A, Cimatti M, Delfini R, Di Pietro V, Finocchiaro A, Lazzarino G. Temporal window of metabolic brain vulnerability to concussions: mitochondrial-related impairment - part i. Neurosurgery. 2007;61(2):379-389.

108. Prins M, Giza CC, Alexander D, Greco T. The pathophysiology of traumatic brain injury at a glance. Dis Mod Mech. 2013;6(6):1307-1315.

109. Povlishock JT, Christman CW. The pathobiology of traumatically induced axonal injury in animals and humans: a review of current thoughts. J Neurotrauma. 1995;12(4):555-564.

110. Lau A, Tymianski M. Glutamate receptors, neurotoxicity and neurodegeneration. Pflügers Arch. 2010;460(2):525-542.

111. Fitzgerald M, Bartlett CA, Harvey AR, Dunlop SA. Early events of secondary degeneration after partial optic nerve transection: an immunohistochemical study. J Neurotrauma. 2010;27(2):439-452.

112. Cornelius C, Crupi R, Calabrese V, Graziano A, Milone P, Pennisi G, Radak Z, Calabrese E, Cuzzocrea S. Traumatic brain injury: oxidative stress and neuroprotection. Antiox Red Sig. 2013;19(8):836-853.

113. Lewen A, Matz P, Chan PH. Free radical pathways in CNS injury. J Neurotrauma. 2010;17(10):871-890.

114. Singh IN, Sullivan PG, Deng Y, Mbye LH, Hall ED. Time course of post-traumatic mitochondrial oxidative damage and dysfunction in a mouse model of focal traumatic brain injury: implications for neuroprotective therapy. J Cereb Blood Flow Metab. 2006;26(11):1407-1418.

115. Pratico D, Reiss P, Tang LX, Sung S, Rokach J, McIntosh TK. Local and systemic increase in lipid peroxidation after moderate experimental traumatic brain injury. J Neurochem. 2002;80(5):894-898.

116. Hall ED, Detloff MR, Johnson K, Kupina NC. Peroxynitritemediated protein nitration and lipid peroxidation in a mouse model of traumatic brain injury. J Neurotrauma. 2004;21(1): 9-20.

117. Higgins GC, Beart PM, Shin YS, Chen MJ, Cheung NS, Nagley P. Oxidative stress: emerging mitochondrial and cellular themes and variations in neuronal injury. J Alzheimers Dis. 2010;20(S2):453-473.

118. Valko M, Leibfritz D, Moncol J, Cronin MT, Mazur M, Telser J. Free radicals and antioxidants in normal physiological functions and human disease. Int $\mathrm{J}$ Biochem Cell Biol. 2007;39(1):44-84.

119. Tavazzi B, Vagnozzi R, Signoretti S, Amorini AM, Belli A, Cimatti M, Delfini R, Di Pietro V, Finocchiaro A, Lazzarino
G. Temporal window of metabolic brain vulnerability to concussions: Oxidative and nitrosative stresses-part ii. Neurosurgery. 2007;61(2):390-396.

120. Di Pietro V, Lazzarino G, Amorini AM, Tavazzi B, D’Urso S, Longo S, Vagnozzi R, Signoretti S, Clementi E, Giardina B, et al. Neuroglobin expression and oxidant/ antioxidant balance after graded traumatic brain injury in the rat. Free Rad Biol Med. 2014;69:258-264.

121. Hall ED, Vaishnav RA, Mustafa AG. Antioxidant therapies for traumatic brain injury. Neurotherapeutics. 2010;7(1):51-61.

122. Smith SL, Andrus PK, Zhang J-R, Hall ED. Direct measurement of hydroxyl radicals, lipid peroxidation, and blood-brain barrier disruption following unilateral cortical impact head injury in the rat. J Neurotrauma. 1994;11(4):393-404.

123. Itoh $T$, Satou $T$, Nishida $S$, Tsubaki M, Imano M, Hashimoto $\mathrm{S}$, Ito $\mathrm{H}$. Edaravone protects against apoptotic neuronal cell death and improves cerebral function after traumatic brain injury in rats. Neurochem Res. 2010;35(2):348-355.

124. Vagnozzi R, Marmarou A, Tavazzi B, Signoretti S, Di Pierro D, Del Bolgia F, Amorini AM, Fazzina G, Giuffré R, Lazzarino G. Changes of cerebral energy metabolism and lipid peroxidation in rats leading to mitochondrial dysfunction after diffuse brain injury. J Neurotrauma. 1999;16(10):903-913.

125. Ansari MA, Roberts KN, Scheff SW. A time course of contusion-induced oxidative stress and synaptic proteins in cortex in a rat model of TBI. J Neurotrauma. 2008;25(5): 513-526.

126. Yamada KH, Kozlowski DA, Seidl SE, Lance S, Wieschhaus AJ, Sundivakkam P, Tiruppathi C, Chishti I, Herman IM, Kuchay SM, et al. Targeted gene inactivation of calpain-1 suppresses cortical degeneration due to traumatic brain injury and neuronal apoptosis induced by oxidative stress. J Biol Chem. 2012;287(16):13182-13193.

127. Higgins G, Beart P, Nagley P. Oxidative stress triggers neuronal caspase-independent death: Endonuclease g involvement in programmed cell death-type iii. Cell Mol Life Sci. 2009;66(16):2773-2787.

128. Bains M, Hall ED. Antioxidant therapies in traumatic brain and spinal cord injury. Biochim Biophys Acta. 2012;1822(5): 675-684.

129. Andersen JK. Oxidative stress in neurodegeneration: cause or consequence? Nat Med. 2004;10(Suppl):S18-S25.

130. Walker KR, Tesco G. Molecular mechanisms of cognitive dysfunction following traumatic brain injury. Front Aging Neurosci. 2013;5(29):10.

131. Casadesus G, Smith MA, Zhu X, Aliev G, Cash AD, Honda K, Petersen RB, Perry G. Alzheimer disease: evidence for a central pathogenic role of iron-mediated reactive oxygen species. J Alzheimer Dis. 2004;6(2):165-169.

132. Uryu K, Laurer H, McIntosh T, Praticò D, Martinez D, Leight S, Lee VMY, Trojanowski JQ. Repetitive mild brain trauma accelerates a $\beta$ deposition, lipid peroxidation, and cognitive impairment in a transgenic mouse model of Alzheimer amyloidosis. J Neurosci. 2002;22(2):446-454.

133. Conte V, Uryu K, Fujimoto S, Yao Y, Rokach J, Longhi L, Trojanowski JQ, Lee VM-Y, McIntosh TK, Praticò D. 
Vitamin E reduces amyloidosis and improves cognitive function in $\operatorname{tg} 2576$ mice following repetitive concussive brain injury. J Neurochem. 2004;90(3):758-764.

134. Ishimaru MJ, Ikonomidou C, Tenkova TI, Dikranian K, Sesma MA, Olney JW. Distinguishing excitotoxic from apoptotic neurodegeneration in the developing rat brain. J Comp Neurol. 1999;408(4):461-476.

135. Nagley P, Higgins GC, Atkin JD, Beart PM. Multifaceted deaths orchestrated by mitochondria in neurones. Biochim Biophys Acta. 2010;1802(1):167-185.

136. Stoica BA, Faden AI. Cell death mechanisms and modulation in traumatic brain injury. Neurotherapeutics. 2010;7(1):3-12.

137. Rink A, Fung K-M, Trojanowski JQ, Lee VM-Y, Neugebauer E, McIntosh TK. Evidence of apoptotic cell death after experimental traumatic brain injury in the rat. Am J Pathol. 1995;147(6):1575-1583.

138. Qui J, Whalen MJ, Lowenstein P, Fiskum G, Fahy B, Darwish R, Aarabi B, Yuan J, Moskowitz MA. Upregulation of the fas receptor death-inducing signaling complex after traumatic brain injury in mice and humans. J Neurosci. 2002;22(9): 3504-3511.

139. Yakovlev AG, Knoblach LF, Fox GB, Goodnight R, Faden AI. Activation of cpp32-like caspases ocntributes to neuronal apoptosis and neurological dysfunction after traumatic brain injury. J Neurosci. 1997;17(19):7415-7424.

140. Nakagawa T, Zhu H, Morishima N, Li E, Xu J, Yanker BA, Yuan J. Caspase-12 mediates endoplasmic-reticulum-specific apoptosis and cytotoxicity by amyloid-b. Nature. 2000; 403(6765):98-103.

141. Larner SF, Hayes RL, McKinsey DM, Pike BR, Wang $\mathrm{KKW}$. Increased expression and processing of caspase-12 after traumatic brain injury in rats. J Neurochem. 2003; 88(1):78-90.

142. Zhang X, Chen J, Graham SH, Du L, Kochanek PM, Draviam R, Guo F, Nathaniel PD, Szabö C, Watkins SC, et al. Intranuclear localization of apoptosis-inducing factor (aif) and large scale DNA fragmentation after traumatic brain injury in rats and in neuronal cultures exposed to peroxynitrite. J Neurochem. 2002;82(1):181-191.

143. Ankarcrona M, Dypbukt JM, Bonfoco E, Zhivotovsky B, Nicotera P. Glutamate-induced neuronal death: a succession of necrosis or apoptosis depending on mitochondrial function. Neuron. 1995;15(4):961-973.

144. Kroemer G, Reed JC. Mitochondrial control of cell death. Nat Med. 2000;6(5):513-519.

145. Raghupathi R. Cell death mechanisms following traumatic brain injury. Brain Pathol. 2004;14(2):215-222.

146. Lotocki G, de Rivero Vaccari JP, Alonso O, Molano JS, Nixon R, Safavi P, Dietrich WD, Bramlett HM. Oligodendrocyte vulnerability following traumatic brain injury in rats. Neurosci Lett. 2011;499(3):143-148.

147. Sullivan MG, Mierzwa JA, Kijpaisalratana $\mathrm{CN}$, Tang $\mathrm{CH}$, Wang CY, Song CS-K, Selwyn CR, Armstrong CR. Oligodendrocyte lineage and subventricular zone response to traumatic axonal injury in the corpus callosum. J Neuropath Exp Neurol. 2013;72(12):1106-1125.
148. Conti AC, Raghupathi R, Trojanoswki JQ, McIntosh TK. Experimental brain injury induces regionally distinct apoptosis during the acute and delayed post-traumatic period. J Neurosci. 1998;18(15):5663-5672.

149. Flygt J, Djupsjo A, Lenne F, Marklund N. Myelin loss and oligodendrocyte pathology in white matter tracts following traumatic brain injury in the rat. Eur J Neurosci. 2013; 38(1):2153-2165.

150. Bolton AN, Saatman KE. Regional neurodegeneration and gliosis are amplified by mild traumatic brain injury repeated at 24hour intervals. J Neuropath Exp Neurol. 2014;73(10):933-947.

151. Luo J, Nguyen A, Villeda S, Zhang H, Ding Z, Lindsey D, Bieri G, Castellano JM, Beaupre GS, Wyss-Coray T. Longterm cognitive impairments and pathological alterations in a mouse model of repetitive mild traumatic brain injury. Front Neurol. 2014;5:12.

152. Kan E-M, Ling E-A, Lu J. Microenvironment changes in mild traumatic brain injury. Brain Res Bull. 2012;87(4-5): 359-372.

153. Abbott NJ, Patabendige AA, Dolman DE, Yusof SR, Begley DJ. Structure and function of the blood-brain barrier. Neurobiol Dis. 2010;37(1):13-25.

154. Abbott NJ, Ronnback L, Hansson E. Astrocyte-endothelial interactions at the blood-brain barrier. Nat Rev Neurosci. 2006;7(1):41-53.

155. Ziebell JM, Morganti-Kossmann MC. Involvement of proand anti-inflammatory cytokines and chemokines in the pathophysiology of traumatic brain injury. Neurotherapeutics. 2010;7(1):22-30.

156. Block ML, Zecca L, Hong J-S. Microglia-mediated neurotoxicity: uncovering the molecular mechanisms. Nat Rev Neurosci. 2007;8(1):57-69.

157. Shlosberg D, Benifla M, Kaufer D, Friedman A. Blood-brain barrier breakdown as a therapeutic target in traumatic brain injury. Nat Rev Neurol. 2010;6(7):393-403.

158. Cherian L, Hlatky R, Roberson CS. Nitric oxide in traumatic brain injury. Brain Pathol. 2004;14(2):195-201.

159. Pan W, Stone KP, Hsuchou H, Manda VK, Zhang Y, Kastin AJ. Cytokine signaling modulates blood-brain barrier function. Curr Pharm Des. 2011;17(33):3729-3740.

160. Persidsky Y, Ramirez SH, Haorah J, Kanmogne GD. Bloodbrain barrier: structural components and function under physiologic and pathologic conditions. J Neuroimmune Pharmacol. 2006;1(3):223-236.

161. Obermeier B, Daneman R, Ransohoff RM. Development, maintenance and disruption of the blood-brain barrier. Nat Med. 2013;19(12):1584-1596.

162. Chodobski A, Zink BJ, Szmydynger-Chodobska J. Bloodbrain barrier pathophysiology in traumatic brain injury. Trans Stroke Res. 2011;2(4):492-516.

163. Fukuda K, Tanno H, Okimura Y, Nakamura M, Yamaura A. The blood-brain barrier disruption to circulating proteins in the early period after fluid percussion brain injury in rats. $\mathrm{J}$ Neurotrauma 1995;12(3):315-324.

164. Whalen MJ, Carlos TM, Kochanek PM, Heineman S. Bloodbrain barrier permeability, neutrophil accumulation and 
vascular adhesion molecule expression after controlled cortical impact in rats: a preliminary study. Acta Neurochir Suppl. 1998;71:212-214.

165. Cernak I, Vink R, Zapple DN, Cruz MI, Ahmed F, Chang T, Fricke ST, Faden AI. The pathobiology of moderate diffuse traumatic brain injury as identified using a new experimental model of injury in rats. Neurobiol Dis. 2004;17(1):29-43.

166. Habgood MD, Bye N, Dziegielewska KM, Ek CJ, Lane MA, Potter A, Morganti-Kossmann C, Saunders NR. Changes in blood-brain barrier permeability to large and small molecules following traumatic brain injury in mice. Eur J Neurosci. 2007;25(1):231-238.

167. Lotocki G, de Rivero Vaccari JP, Perez ER, Sanchez-Molano J, Furones-Alonso O, Bramlett HM, Dietrich WD. Alterations in blood-brain barrier permeability to large and small molecules and leukocyte accumulation after traumatic brain injury: effects of post-traumatic hypothermia. J Neurotrauma. 2009; 26(7):1123-1134.

168. Dore-Duffy P, Owen C, Balabanov R, Murphy S, Beaumont $\mathrm{T}$, Rafols JA. Pericyte migration from the vascular wall in response to traumatic brain injury. Microvasc Res. 2000; 60(1):55-69.

169. Brock JB, Yanuck S, Pierce M, Powell M, Geanopulos S, Noseworthy S, Kharrazian D, Turnpaugh C, Comey A, Zielinski G. The potential impact of various physiological mechanisms on outcomes in tbi, mtbi, concussion and ppcs. Funct Neurol Rehab Erg. 2013;3(2-3):215-256.

170. Chen S, Pickard JD, Harris NG. Time course of cellular pathology after controlled cortical impact injury. Exp Neurol. 2003;182(1):87-102.

171. Liu MC, Akle V, Zheng W, Kitlen J, O'Steen B, Larner SF, Dave JR, Tortella FC, Hayes RL, Wang KK. Extensive degradation of myelin basic protein isoforms by calpain following traumatic brain injury. J Neurochem. 2006;98(3):700-712.

172. Sofroniew MV, Vinters HV. Astrocytes: biology and pathology. Acta Neuropathol. 2010;119(1):7-35.

173. Torrente D, Cabezas R, Avila MF, García-Segura LM, Barreto GE, Guedes RCA. Cortical spreading depression in traumatic brain injuries: is there a role for astrocytes? Neurosci Lett. 2014;565:2-6.

174. Burda JE, Bernstein AM, Sofroniew MV. Astrocyte roles in traumatic brain injury. Exp Neurol. 2015;275(3):305-315.

175. Davalos D, Grutzendler J, Yang G, Kim JV, Zuo Y, Jung S, Littman DR, Dustin ML, Gan W-B. ATP mediates rapid microglial response to local brain injury in vivo. Nat Neurosci. 2005;8(6):752-758.

176. Hill SJ, Barbarese E, McIntosh TK. Regional heterogeneity in the response of astrocytes following traumatic brain injury in the adult rat. J Neuropath Expl Neurol. 1996;55(12): 1221-1229.

177. Myer DJ, Gurkoff GG, Lee SM, Hovda DA, Sofroniew MV. Essential protective roles of reactive astrocytes in traumatic brain injury. Brain. 2006;129(10):2761-2772.

178. Cortez SC, McIntosh TK, Noble LJ. Experimental fluid percussion brain injury: vascular disruption and neuronal and glial alterations. Brain Res. 1989;482(2):271-282.
179. Sofroniew MV. Molecular dissection of reactive astrogliosis and glial scar formation. Trends in Neurosci. 2009;32(12): 638-647.

180. Mouzon BC, Bachmeier C, Ferro A, Ojo JO, Crynen G, Acker CM, Davies P, Mullan M, Stewart W, Crawford F. Chronic neuropathological and neurobehavioral changes in a repetitive mild traumatic brain injury model. Ann Neurol. 2014; 75(2):241-254.

181. Gehrmann J, Masumoto Y, Kreutzberg GW. Microglia: intrinsic immuneffector cell of the brain. Brain Res Brain Res Rev. 1995;20(3):269-287.

182. Loane DJ, Kumar A, Stoica BA, Cabatbat R, Faden AI. Progressive neurodegeneration after experimental brain trauma: association with chronic microglial activation. J Neuropathol Exp Neurol. 2014;73(1):14-29.

183. Kelley BJ, Lifshitz J, Povlishock JT. Neuroinflammatory responses after experimental diffuse traumatic brain injury. J Neuropathol Exp Neurol. 2007;66(11):989-1001.

184. Kumar A, Loane DJ. Neuroinflammation after traumatic brain injury: opportunities for therapeutic intervention. Brain Behav Immun. 2012;26(8):1191-1201.

185. Morganti-Kossmann MC, Rancan M, Stahel PF, Kossmann T. Inflammatory response in acute traumatic brain injury: a double- edged sword. Curr Opin Crit Care. 2002;8(2):101-105.

186. Brody DL, Benetatos J, Bennett RE, Klemenhagen KC, Mac Donald CL. The pathophysiology of repetitive concussive traumatic brain injury in experimental models; new developments and open questions. Mol Cell Neurosci. 2015;66(B):91-98.

187. Smith C, Gentleman SM, Leclercq PD, Murray LS, Griffin WST, Graham DI, Nicoll JAR. The neuroinflammatory response in humans after traumatic brain injury. Neuropathol Appl Neurobiol. 2013;39(6):654-666.

188. Schmidt OI, Heyde CE, Ertel W, Stahel PF. Closed head injury - an inflammatory disease? Brain Res Brain Res Rev. 2005;48(2):388-399.

189. Nakagawa Y, Chiba K. Role of microglial M1/M2 polarization in relapse and remission of psychiatric disorders and diseases. Pharmaceuticals. 2014;7(12):1028-1048.

190. Soltys Z, Ziaja M, Pawliński R, Setkowicz Z, Janeczko K. Morphology of reactive microglia in the injured cerebral cortex. Fractal analysis and complementary quantitative methods. J Neurosci Res. 2001;63(1):90-97.

191. Blaylock R, Maroon J. Immunoexcitotoxicity as a central mechanism in chronic traumatic encephalopathy-a unifying hypothesis. Surg Neurol Int. 2011;2(1):107.

192. Smith DH, Meaney DF, Shull WH. Diffuse axonal injury in head trauma. J Head Trauma Rehab. 2003;18(4):307-316.

193. Johnson VE, Stewart W, Smith DH. Axonal pathology in traumatic brain injury. Exp Neurol. 2013;246:35-43.

194. Ommaya AK, Hirsch AE. Tolerances for cerebral concussion from head impact and whiplash in primates. J Biomech 1971; 4(1):13-21.

195. Bramlett HM, Dietrich WD. Long-term consequences of traumatic brain injury: current status of potential mechanisms of injury and neurological outcomes. J Neurotrauma. 2015; 32(23):1834-1848. 
196. Pettus EH, Christman CW, Giebel ML, Povlishock JT. Traumatically induced altered membrane permeability: its relationship to traumatically induced reactive axonal change. J Neurotrauma. 1994;11(5):507-522.

197. Smith DH, Hicks R, Povlishock JT. Therapy development for diffuse axonal injury. J Neurotrauma. 2013;30(5):307-323.

198. Nakamura Y, Takeda M, Angelides KJ, Tanaka T, Tada K, Nishimura T. Effect of phosphorylation on 68 kda neurofilament subunit protein assembly by the cyclic amp dependent protein kinase in vitro. Biochem Biophys Res Commun. 1990;169(2):744-750.

199. Maxwell WL, Povlishock JT, Graham DL. A mechanistic analysis of nondisruptive axonal injury: a review. J Neurotrauma. 1997;14(7):419-440.

200. Pierce JES, Smith DH, Trojanoswki JQ, McIntosh TK. Enduring cognitive, neurobehavioral and histopathological changes persist for up to one year following severe experimental brain injury in rats. Neuroscience. 1998;87(2):359-369.

201. Smith DH, Meaney DF. Axonal damage in traumatic brain injury. Neuroscientist. 2000;6(6):483-495.

202. Bramlett HM, Kraydieh S, Green EJ, Dietrich WD. Temporal and regional patterns of axonal damage following traumatic brain injury: a beta-amyloid precursor protein immunocytochemical study in rats. J Neuropathol Exp Neurol. 1997; 56(10):1132-1141.

203. Singleton RH, Zhu J, Stone JR, Povlishock JT. Traumatically induced axotomy adjacent to the soma does not result in acute neuronal death. J Neuroscience. 2002;22(3):791-802.

204. Reeves TM, Phillips LL, Povlishock JT. Myelinated and unmyelinated axons of the corpus callosum differ in vulnerability and functional recovery following traumatic brain injury. Exp Neurol. 2005;196(1):126-137.

205. Dixon CE, Kochanek PM, Yan HQ, Schiding JK, Griffith RG, Baum E, Marion DW, DeKosky ST. One-year study of spatial memory performance, brain morphology, and cholinergic markers after moderate controlled cortical impact in rats. J Neurotrauma. 1999;16(2):109-122.

206. Hawkins BE, Krishnamurthy S, Castillo-Carranza DL, Sengupta U, Prough DS, Jackson GR, DeWitt DS, Kayed R. Rapid accumulation of endogenous tau oligomers in a rat model of traumatic brain injury: possible link between traumatic brain injury and sporadic tauopathies. J Biol Chem. 2013;288(23):17042-17050.

207. Biernat J, Gustke N, Drewes G, Mandelkow EM, Mandelkow E. Phosphorylation of ser262 strongly reduces binding of tau to microtubules: distinction between phf-like immunoreactivity and microtubule binding. Neuron. 1993; 11(1):153-163.

208. Johnson GV, Stoothoff WH. Au phosphorylation in neuronal cell function and dysfunction. J Cell Sci. 2004;117(24): 5721-5729.

209. Blennow K, Hardy J, Zetterberg H. The neuropathology and neurobiology of traumatic brain injury. Neuron. 2012;76(5): 886-899.

210. Bigler ED. Neuroimaging biomarkers in mild traumatic brain injury (mtbi). Neuropsychol Rev. 2013;23(3):169-209.
211. Fujita M, Wei EP, Povlishock JT. Intensity- and intervalspecific repetitive traumatic brain injury can evoke both axonal and microvascular damage. J Neurotrauma. 2012; 29(12):2172-2180.

212. Longhi L, Saatman KE, Fujimoto S, Raghupathi R, Meaney DF, Davis J, McMillan B S A, Conte V, Laurer HL, Stein S, et al. Temporal window of vulnerability to repetitive experimental concussive brain injury. Neurosurgery. 2005;56(2): 364-374.

213. Bennett R, Brody D. Acute reduction of microglia does not alter axonal injury in a mouse model of repetitive concussive traumatic brain injury. J Neurotrauma 2014;31(19): 1647-1663.

214. Ojo JO, Mouzon B, Greenberg M, Bachmeier C, Mullan M, Crawford F. Repetitive mild traumatic brain injury augments tau pathology and glial activation in aged $\mathrm{h}$ tau mice. J Neuropathol Exp Neurol. 2013;72(2):137-151.

215. Yoshiyama Y, Uryu K, Higuchi M, Lee VMY, Trojanowski JQ, Longhi L, Hoover R, Fujimoto S, McIntosh T. Enhanced neurofibrillary tangle formation, cerebral atrophy, and cognitive deficits induced by repetitive mild brain injury in a transgenic tauopathy mouse model. J Neurotrauma. 2005;22(10): 1134-1141.

216. Gavett BE, Stern RA, McKee AC. Chronic traumatic encephalopathy: a potential late effect of sport-related concussive and subconcussive head trauma. Clin Sports Med. 2011; 30(1):179-188.

217. Yoshiyama Y, Uryu K, Higuchi M, Longhi L, Hoover R, Fujimoto S, McIntosh T, Lee VM, Trojanowski JQ. Enhanced neurofibrillary tangle formation, cerebral atrophy, and cognitive deficits induced by repetitive mild brain injury in a transgenic tauopathy mouse model. J Neurotrauma. 2005;22(10): 1134-1141.

218. Mierzwa JA, Marion MC, Sullivan MG, McDaniel PD, Armstrong CR. Components of myelin damage and repair in the progression of white matter pathology after mild traumatic brain injury. J Neuropathol Exp Neurol. 2015;74(3): $218-232$

219. Abdel Baki SG, Schwab B, Haber M, Fenton AA, Bergold PJ. Minocycline synergizes with n-acetylcysteine and improves cognition and memory following traumatic brain injury in rats. PLoS One. 2010;5(8):e12490.

220. Spain A, Daumas S, Lifshitz J, Rhodes J, Andrews PJD, Horsburgh K, Fowler JH. Mild fluid percussion injury in mice produces evolving selective axonal pathology and cognitive deficits relevant to human brain injury. J Neurotrauma. 2010; 27(8):1429-1438.

221. Creed JA, DiLeonardi AM, Fox DP, Tessler AR, Raghupathi $R$. Concussive brain trauma in the mouse results in acute cognitive deficits and sustained impairment of axonal function. J Neurotrauma. 2011;28(4):547-563.

222. Shultz SR, MacFabe DF, Foley KA, Taylor R, Cain DP. A single mild fluid percussion injury induces short-term behavioral and neuropathological changes in the Long-Evans rat: support for an animal model of concussion. Behav Brain Res. 2011;224(2):326-335. 
223. McTigue DM, Tripathi RB. The life, death, and replacement of oligodendrocytes in the adult cns. J Neurochem. 2008; 107(1):1-19.

224. Connor JR, Menzies SL. Relationship of iron to oligodendrocytes and myelination. Glia. 1996;17(2):83-93.

225. Thorburne S, Juurlink B. Low glutathione and high iron govern the susceptibility of oligodendroglial precursors to oxidative stress. J Neurochem. 1996;67(3):1014-1022.

226. Fitzgerald M, Wells J, Kilburn M, Bartlett C, Shaw J, Harvey A, Dunlop S. Oxidative stress in astrocytes following partial injury to a CNS tract. Glia. 2011;59:S74.

227. Matute C, Alberdi E, Domercq M, Sánchez-gómez MV, Pérez-samartín A, Rodríguez-antigüedad A, Pérez-cerdá F. Excitotoxic damage to white matter. J Anat. 2007;210(6): 693-702.

228. Bongarzone ER, Pasquini JM, Soto EF. Oxidative damage to proteins and lipids of cns myelin produced by in vitro generated reactive oxygen species. J Neurosci Res. 1995;41(2):213-221.

229. Back SA, Gan X, Li Y, Rosenberg PA, Volpe JJ. Maturationdependent vulnerability of oligodendrocytes to oxidative stress-induced death caused by glutathione depletion. J Neurosci. 1998;18(16):6241-6253.

230. van der Goes A, Brouwer J, Hoekstra K, Roos D, van den Berg TK, Dijkstra CD. Reactive oxygen species are required for the phagocytosis of myelin by macrophages. J Neuroimmunol. 1998;92(1):67-75.

231. Rhodes KE, Raivich G, Fawcett JW. The injury response of oligodendrocyte precursor cells is induced by platelets, macrophages and inflammation- associated cytokines. Neuroscience. 2006;140(1):87-100.

232. Seo JH, Miyamoto N, Hayakawa K, Pham LD, Maki T, Ayata C, Kim KW, Lo EH, Arai K. Oligodendrocyte precursors induce early blood-brain barrier opening after white matter injury. J Clin Invest. 2013;123(2):782-786.

233. Bramlett HM, Dietrich WD. Quantitative structural changes in white and gray matter 1 year following traumatic brain injury in rats. Acta Neuropathol. 2002;103(6):607-614.

234. Rodriguez-Paez AC, Brunschwig JP, Bramlett HM. Light and electron microscopic assessment of progressive atrophy following moderate traumatic brain injury in the rat. Acta Neuropathol. 2005;109(6):603-616.

235. Huh JW, Widing AG, Raghupathi R. Repetitive mild noncontusive brain trauma in immature rats exacerbates traumatic axonal injury and axonal calpain activation. J Neurotrauma. 2007;24(1):15-27.

236. Prins ML, Hales A, Reger M, Giza CC, Hovda DA. Repeat traumatic brain injury in the juvenile rat is associated with increased axonal injury and cognitive impairments. Dev Neurosci. 2010;32(5-6):510-518.

237. Donders J, Strong CA. Clinical utility of the wechsler adult intelligence scale-fourth edition after traumatic brain injury. Assessment. 2015;22(1):17-22.

238. Dams-O'Connor K, Spielman L, Singh A, Gordon WA, Lingsma HF, Maas AI, Manley GT, Mukherjee P, Okonkwo DO, Puccio AM, et al; TRACK-TBI Investigators. The impact of previous traumatic brain injury on health and functioning: a TRACK-TBI study. J Neurotrauma. 2013; 30(24):2014-2020.

239. Gold E, Su D, Löpez-Veläzquez L, Haus DL, Perez H, Lacuesta GA, Anderson AK, Cummings BJ. Functional assessment of long-term deficits in rodent models of traumatic brain injury. Regen Med. 2013;8(4):483-516.

240. Webster KM, Wright DK, Sun M, Semple BD, Ozturk E, Stein DG, O'Brien TJ, Shultz SR. Progesterone treatment reduces neuroinflammation, oxidative stress and brain damage and improves long-term outcomes in a rat model of repeated mild traumatic brain injury. $\mathrm{J}$ Neuroinflammation. 2015;12:238

241. Miyauchi T, Wei EP, Povlishock JT. Therapeutic targeting of the axonal and microvascular change associated with repetitive mild traumatic brain injury. J Neurotrauma. 2013;30(19): 1664-1671.

242. Zhang J, Teng Z, Song Y, Hu M, Chen C. Inhibition of monoacylglycerol lipase prevents chronic traumatic encephalopathy-like neuropathology in a mouse model of repetitive mild closed head injury. J Cereb Blood Flow Metab. 2015;35(3):443-453.

243. Kondo A, Shahpasand K, Mannix R, Qiu J, Moncaster J, Chen CH, Yao Y, Lin YM, Driver JA, Sun Y, et al. Antibody against early driver of neurodegeneration cis p-tau blocks brain injury and tauopathy. Nature 2015;523(7561): 431-436.

244. Tan XL, Wright DK, Liu S, Hovens C, O’Brien TJ, Shultz SR. Sodium selenate, a protein phosphatase $2 \mathrm{a}$ activator, mitigates hyperphosphorylated tau and improves repeated mild traumatic brain injury outcomes. Neuropharmacology. 2016; 108:382-393.

245. Wang T, Van KC, Gavitt BJ, Grayson JK, Lu YC, Lyeth BG, Pichakron KO. 2Effect of fish oil supplementation in a rat model of multiple mild traumatic brain injuries. Rest Neurol Neurosci. 2013;31(5):647-659.

246. Namjoshi DR, Cheng WH, Carr M, Martens KM, Zareyan S, Wilkinson A, McInnes KA, Cripton PA, Wellington CL. Chronic exposure to androgenic-anabolic steroids exacerbates axonal injury and microgliosis in the chimera mouse model of repetitive concussion. PLoS One. 2016;11(1): e0146540.

247. Friess SH, Ichord RN, Ralston J, Ryall K, Helfaer MA, Smith C, Margulies SS. Repeated traumatic brain injury affects composite cognitive function in piglets. J Neurotrauma. 2009;26(7):1111-1121.

248. Raghupathi R, Mehr M, Helfaer MA, Margulies SS. Traumatic axonal injury is exacerbated following repetitive closed head injury in the neonatal pig. J Neurotrauma. 2004;21(3):307-316.

249. Yuen TJ, Browne KD, Iwata A, Smith DH. Sodium channelopathy induced by mild axonal trauma worsens outcome after a repeat injury. J Neurosci Res. 2009;87(16):3620-3625.

250. Slemmer JE, Matser EJT, De Zeeuw CI, Weber JT. Repeated mild injury causes cumulative damage to hippocampal cells. Brain. 2002;125(12):2699-2709.

251. Sengupta $P$. The laboratory rat: relating its age with human's. Int J Prev Med. 2013;4(6):624-630. 
252. Al Nimer F, Lindblom R, Strom M, Guerreiro-Cacais AO, Parsa R, Aeinehband S, Mathiesen T, Lidman O, Piehl F. Strain influences on inflammatory pathway activation, cell infiltration and complement cascade after traumatic brain injury in the rat. Brain Behav Immun. 2013;27(1):109-122.

253. Roof RL, Hall ED. Estrogen-related gender difference in survival rate and cortical blood flow after impact-acceleration head injury in rats. J Neurotrauma. 2000;17(12):1155-1169.

254. Broshek DK, Kaushik T, Freeman JR, Erlanger D, Webbe F, Barth JT. Sex differences in outcome following sports-related concussion. J Neurosurg. 2005;102(5):856-863.

255. Prins ML, Hovda DA. Developing experimental models to address traumatic brain injury in children. J Neurotrauma. 2003;20(2):123-137

256. Prins ML, Alexander D, Giza CC, Hovda DA. Repeated mild traumatic brain injury: mechanisms of cerebral vulnerability. J Neurotrauma. 2013;30(1):30-38.

257. Goddeyne C, Nichols J, Wu C, Anderson T. Repetitive mild traumatic brain injury induces ventriculomegaly and cortical thinning in juvenile rats. J Neurophysiol. 2015;113(9): 3268-3280.

258. Sultana R, Perluigi M, Butterfield D. Protein oxidation and lipid peroxidation in brain of subjects with Alzheimer's disease: insights into mechanism of neuro degeneration from redox proteomics. Antiox Red Sig. 2006;8(11 and 12): 2021-2037.

259. Kinnunen KM, Greenwood R, Powell JH, Leech R, Hawkins PC, Bonnelle V, Patel MC, Counsell SJ, Sharp DJ. White matter damage and cognitive impairment after traumatic brain injury. Brain. 2010;134(2):449-463.

260. Madathil SK, Carlson SW, Brelsfoard JM, Ye P, D'Ercole AJ, Saatman KE. Astrocyte-specific overexpression of insulinlike growth factor-1 protects hippocampal neurons and reduces behavioral deficits following traumatic brain injury in mice. PLoS One. 2013;8(6):e67204.

261. Homsi S, Piaggio T, Croci N, Noble F, Plotkine M, Marchand-Leroux C, Jafarian-Tehrani M. Blockade of acute microglial activation by minocycline promotes neuroprotection and reduces locomotor hyperactivity after closed head injury in mice: a twelve-week follow-up study. J Neurotrauma. 2010;27(5):911-921.
262. Smith DH, Johnson VE, Stewart W. Chronic neuropathologies of single and repetitive tbi: Substrates of dementia? Nat Rev Neurol. 2013;9(4):211-221.

263. Wieloch T, Nikolich K. Mechanisms of neural plasticity following brain injury. Curr Opin Neurobiol. 2006;16(3): $258-264$

264. Dupret D, Revest JM, Koehl M, Ichas F, De Giorgi F, Costet P, Abrous DN, Piazza PV. Spatial relational memory requires hippocampal adult neurogenesis. PLoS One. 2008;3(4): e1959.

265. Tzekov R, Quezada A, Gautier M, Biggins D, Frances C, Mouzon B, Jamison J, Mullan M, Crawford F. Repetitive mild traumatic brain injury causes optic nerve and retinal damage in a mouse model. J Neuropathol Exp Neurol. 2014;73(4):345-361.

266. Klemenhagen KC, O'Brien SP, Brody DL. Repetitive concussive traumatic brain injury interacts with post-injury foot shock stress to worsen social and depression-like behavior in mice. PLoS One. 2013;8(9):e74510.

267. Kanayama G, Takeda M, Niigawa H, Ikura Y, Tamii H, Taniguchi N, Kudo T, Miyamae Y, Morihara T, Nishimura T. The effects of repetitive mild brain injury on cytoskeletal protein and behavior. Methods Find Exp Clin Pharmacol. 1996;18(2): $105-115$.

268. Deross LA, Adams EJ, Vane WD, Russell JS, Terella MA, Wald LS. Multiple head injuries in rats: effects on behavior. J Trauma. 2002;52(4):708-714.

269. Allen GV, Gerami D, Esser MJ. Conditioning effects of repetitive mild neurotrauma on motor function in an animal model of focal brain injury. Neuroscience. 2000;99(1): 93-105.

270. Nichols JN, Deshane AS, Niedzielko TL, Smith CD, Floyd CL. Greater neurobehavioral deficits occur in adult mice after repeated, as compared to single, mild traumatic brain injury (mtbi). Behav Brain Res. 2016;298(B):111-124.

271. Xu L, Nguyen JV, Lehar M, Menon A, Rha E, Arena J, Ryu J, Marsh-Armstrong N, Marmarou CR, Koliatsos VE. Repetitive mild traumatic brain injury with impact acceleration in the mouse: multifocal axonopathy, neuroinflammation, and neurodegeneration in the visual system. Exp Neurol. 2016; 275(Pt 3):436-449. 